Portland State University

PDXScholar

$11-24-1976$

\title{
Volunteers in Portland Schools: Initial Planning and Early Development
}

Mary B. Norville

Portland State University

Follow this and additional works at: https://pdxscholar.library.pdx.edu/open_access_etds

Part of the Education Commons

Let us know how access to this document benefits you.

\section{Recommended Citation}

Norville, Mary B., "Volunteers in Portland Schools: Initial Planning and Early Development" (1976). Dissertations and Theses. Paper 2558.

https://doi.org/10.15760/etd.2555

This Thesis is brought to you for free and open access. It has been accepted for inclusion in Dissertations and Theses by an authorized administrator of PDXScholar. Please contact us if we can make this document more accessible: pdxscholar@pdx.edu. 
AN ABSTRACI OF THE THESIS OF Mary B. Norville for the Master of Science in Education presented November $24,1976$.

Mitle: Volunteers in Portland Schools: Iystial Planning and Early Development.

APPROVED BY MEMBERS OF THE THESIS COMMITTEE:

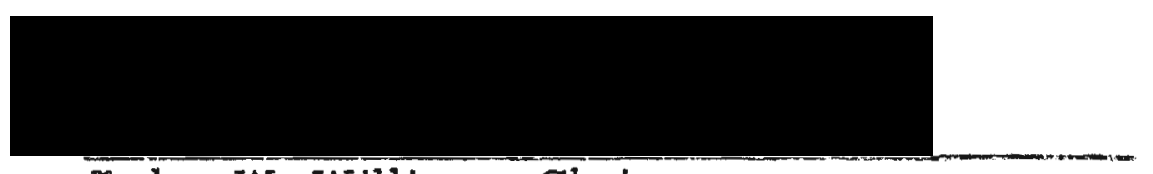

Forbes W. Williams, Chairman

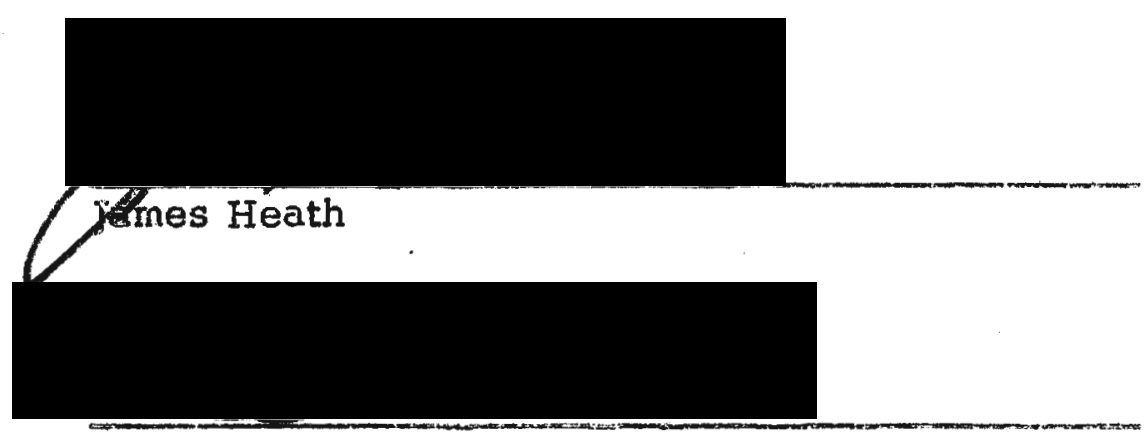

Charles Clemans

The subject of this thesis focuses on the early develcpment of Ficlunteers tri Portand Schools. Commonly referred to as VIPS, this progrem was designed to coordinate and optimize the use of volunteers Ghoughcut the school district. VJFs is jointly sponsored by the Portland Zublic schools and the Portland Council, P. T.A. and is funded by the Fortland Fublic Schools.

The VIPS concept was conceiryed by the author of this thests in August 1968. A proposal for a cooperative school volunteer program 
was written in the fall of that year with the endorsement of the School Board and the assistance of school district personnel. Th1s proposal was approved and adopted by the Board February 1969 and the author was directed to coordinate a VIPS pllot project in the Cleveland High School area from February until June 1969. In June the School Board expanded the program cltywide and hired a part-time director. The author continued in the role of section coordinator for the Cleveland High School area during the school year 1969-1970.

The discussion of the VIPS program in this thesis is essentially historical and is based on the direct experiences of the author. The paper reviews the conception, establishment, and early development of Volunteers in Portland Schools, particularly as they relate to the Cleveland High School area in the period 1969 to 1970. As a prelude to this discussion, attention also focuses on the school volunteer movement nationally as well as locally in selected cities. As a postscript, a later view, 1975-1976, briefly illustrates the growth of school volunteer programs on both the local and national scene.

Statistical information found in the thesis focuses on 1) utllization of volunteers and 2) attitudes of volunteers toward support of the school district and volunteerism during the period January to July 1970 In the Cleveland High School District, an area comprising one high school and ten feeder elementary schools.

Data for a survey of volunteer assignments was obtained from a 
serles of four reply cards sent to all volunteers in the Cleveland area. Volunteers were asked to provide information on the nature of their volunteer assignment, number of hours worked, grade level, and school for the weeks of January 12, February 23, April 13, and June 1, 1970. This information is illustrated by Tables I, II, and III, pages 50 to 52 of this thesis.

Data on volunteer attitudes was obtained from a questionnaire administered as a pre- and post test to approximately one hundred seventy VIPS volunteers working in the Cleveland area. The pretest was malled to volunteers January 3,1970 and the post test was mailed July 2,1970 . The questionnaire contained ten statements to which volunteers were asked their level of agreement or disagreement. From the response to these questionnaires it would appear that volunteer service, with its consequent opportunity to gain an understanding of school problems, may be associated with support for school needs and for school volunteerism. This level of support is illustrated by Figures $3,4,5$ and 6 on pages 59 to 62 of this thesis. 
VOLUNTEERS IN PORTLAND SCHOOLS: INITIAL

PIANNING AND EARLY DEVELOPMENT

by

MARY B. NORVILLE

A thesis submitted in partial fulfillment of the requirements for the degree of

\author{
MASTER OF SCIENCE \\ in \\ EDUCATION
}

Portland State University

1976 
TO THE OFFICE OF GRADUATE STUDIES AND RESEARCH:

The members of the Committee approve the thesis of

Mary B. Norville presented November 24, 1976.

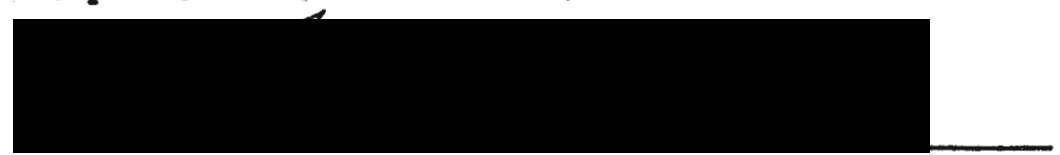

Forbes W. Williams, Chairman

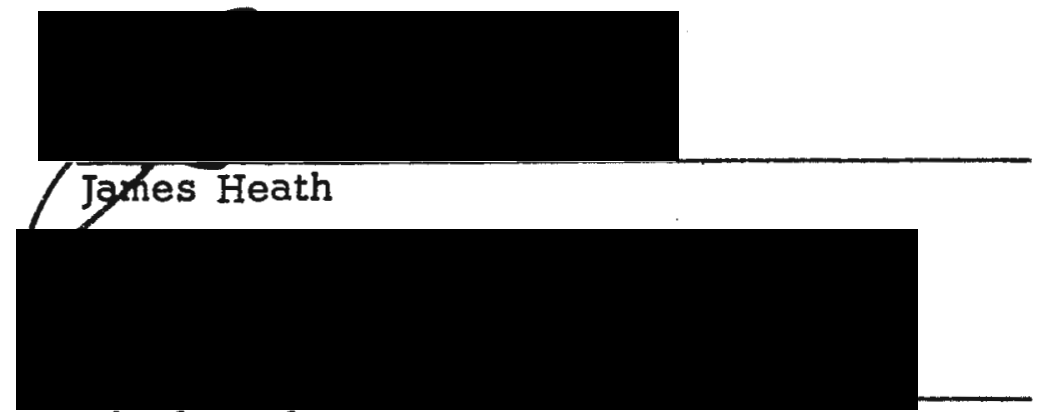

Charles Clemans

APPROVED:

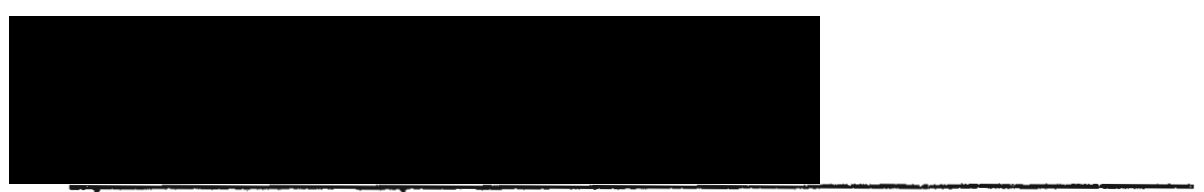

Ronald G. Petrie, Dean, School of Education

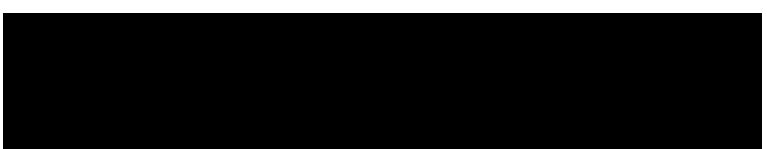

Stănley E. Rauch, Dean of Graduate Studies and Research 


\section{ACKNOWLEDGEMENTS}

The author is indebted to the Portland Public Schools for assistance in the establishment of the VIPS Pilot Profect, for help with the design and preparation of evaluative Instruments, and for printing of figures and appendices found in this thesis. 
TABLE OF CONTENTS

PAGE

ACKNOWLEDGEMENTS. .....................

LIST OF TABLES.......................... vil

LIST OF ILLUSTRATIONS. ................... vili

CHAPTER

I INTRODUCTION.................... 1

III INITIAL PLANNING.................. 7

Definition of the Problem.............. 8

The Problem at the Neighborhood School

The Problem District-Wide

Summary of the Problem

Basic Assumptions................. 10

Goals........................ 11

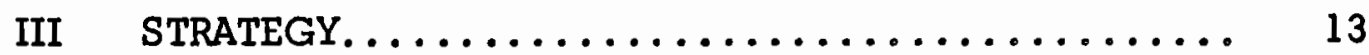

Research and Comparisons.............. 13

National School Volunteer Program, Inc.

School Volunteer Programs in Selected Cities

Structure of the Portland Program...........

Levels of Organization

Guidelines of the Portland Program......... 20

Initlation of the Program............. 21

Evaluation of the Pilot Project............ 21 
Summary..................... 22

IV OPERATION OF THE PILOT PROJECT............. 24

Philosophy of the Pllot Project........... 25

Development of Materials and Operational

Procedures......................... 26

The Program in the Schools............... 26

Evaluation of the Pilot Project............ 29

Expansion of the Program.............. 32

V EXAMINATION AND EVALUATION............. 34

Basic Assumption $\# 1 \ldots \ldots \ldots \ldots \ldots \ldots \ldots \ldots \ldots . \ldots . \ldots$

Basic Needs as Listed by Dr. Rainman

Evidence of Meeting these Basic Needs

Basic Assumption \#2.................. 40

Basic Assumption \#3.................. 41

Generally Large Classes

Teaching Time Consumed by Non-Teaching Tasks

Volunteers Provide Enrichment

Volunteer Assistance in Portland, January to June 1970

Basic Assumption \#4.................... 49

Local Testing of Assumption \#4

vI CONCLUSIONS AND RECOMMENDATIONS......... 63

Changing Role of VIPS Director............ 63

Orientation, Pre-Service, and Inservice Programs Internal Public Relations

Resource Search

Requirements at the Local Level. ............ 67 
Program Support from Principals and Staff

Capable Personnel in Coordinating Positions

Summary

69

VII POSTSCRIPT: THE PROGRAM AFTER SEVEN YEARS.... 71

The National Scene.................. 7.1

The Local Scene................... 72

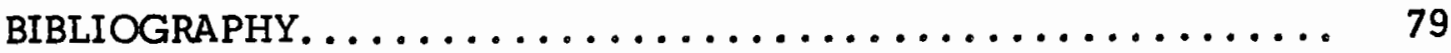

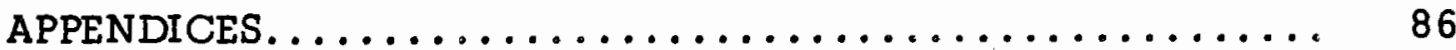




\section{LIST OF TABLES}

TABLE

PAGE

I. Survivey of Volunteer Assignments

in the Cleveland High School

Area, winter and spring 1970.... 50

II. Volunteer Assignments for Teaching

Tasks in the Cleveland High

School Area, winter and Spring

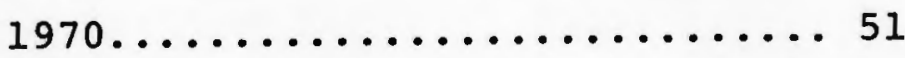

III. Volunteer Assignments for

Non-Teaching Tasks in the

Cleveland High School Area,

winter and spring 1970....... 52 


\section{LIST OF ILLUSTRATIONS}

FIGURE

PAGE

1. Proposed Organizational Structure: Volunteers in

Portland Schools, February 1969

2. Summary of School Volunteer Programs, VIPS Pilot

Project, February to June $1970 . \ldots \ldots \ldots \ldots \ldots$

28

3. Level of Support for the Portland Public Schools as

Shown by Responses to Statements $1,2,3$,

and 10 of a Questionnaire Given to Volunteers

in Portland Schools, January $1970 . . \ldots \ldots \ldots$

4. Level of Support for the Portland Schools as Shown

by Responses to Statements $1,2,3$ and 10

of a Questionnaire Given to Volunteers in

Portland Schools, July 1970

5. Level of Support for the Act of Volunteering in

Schools as Shown by Responses to Statements

5, 7 and 9 of a Questionnaire Given to Volunteers

in Portland Schools, January $1970 . \ldots \ldots \ldots \ldots$

6. Level of Support for the Act of Volunteering in

Schools as Shown by Responses to Statements

5, 7 and 9 of a Questionnaire Given to Volunteers

in Portland Schools, July $1970 . \ldots \ldots \ldots \ldots \ldots$ 
7. Volunteers in Portland Schools Organizational

Structure, $1976 \ldots \ldots \ldots \ldots \ldots \ldots \ldots \ldots \ldots .74$

8. Organization of Volunteers in Portland Schools

Program in Participating Schools, 1976....... 75 


\section{CHAPTER I}

\section{INTRODUCTION}

Since World War II the United States has witnessed a dramatic change in metropolitan life. During the last twenty-five years urbanization has coincided with a period of rapid technological, social, and economic upheaval which has in part contributed to the formerly unorganized and sprawling metropolis. In $1967,70 \%$ of the American public lived in an urban environment. ${ }^{1}$ Forecasts for the future predict that the percentage of urban dwellers will grow even larger. The city of today "not only increasingly dominates the whole of American society but indeed IS American society." ${ }^{2}$ This situation has led William Stringfellow, lawyer, author, and outs poken Christian layman, to conclude that the city represents today's frontier for many of America's social, political, and economic institutions. ${ }^{3}$

The crisis faced by the center city has been well described by Kerber and Bommarito, in an introduction to a discussion of the changing urban community:

${ }^{1}$ Scientific American, Cities (New York: Alfred A. Knopf, Inc., 1967), p. V.

${ }^{2}$ William Stringfellow, Free in Obedience (New York: The Seabury Press, 1964), p. 18.

$3_{\text {Ibid. }}$ 
The decentralization of business and commerce has emasculated the once dynamic urban center. Slum and blight rush into a vacuum created by a retreating middle class, and urban renewal runs a losing race aga inst decay. The city lacks adequate funds to meet rising operational costs, but finds that it must compete with outlying independent communities for tax resources. Social agencies are overwhelmed by cases of the unemployed and unemployable; the indigent who are displaced by slum clearance; and the marginal and alienated who can not find identity, dignity, or aspiration in the urban society containing a complex of disparate nonintegrated roles and a lack of primary relations. ${ }^{4}$

Education has felt the full impact of this urban crisis. The school system, as part of a larger society, is caught up in today's major social and technological revolutions. Beset by financial woes and a multitude of complex problems, the urban schools are finding it an increasing challenge to achieve their primary goals - to provide students with the "intellectual, technical, and moral wherewithal for adult life." ${ }^{5}$ For this reason, the role of the school in the urban context requires serious examination.

Much recent literature addresses itself to the need to bring the schools closer to their constituency. In outlining his plan for Portland's schools in the '70's, Superintendent Robert W. Blanchard

4 August Kerber and Barbara Bommarito, eds., The Schools and the Urban Crisis (New York: Holt, Rinehart and Winston, 1965), p. V.

${ }^{5}$ Eleanor Bernet Sheldon, James R. Hudson, and Raymond A. Glazier, "Administrative Implications of Integration Plans for Schools: Open Enrollment in New York City," in Schools in a Changing Society. ed. by Albert J. Reiss, Jr. (New York: The Free Press, 1965), p. 156. 
gave specific attention to this necessity as he called for decentralization of the school system. As stated by Dr. Blanchard:

The need is imperative to provide a better response to community and staff needs and concerns, to reduce the steps required to secure decisions on matters initiated by teachers, parents, or students, and to allow more direct and productive involvement of the community and staff in school affairs. 6

While decentralization as advocated by Dr. Blanchard appears to be a very real and major step toward achieving a closer relationship between school and community, it alone cannot do the job. Other avenues must also be found to encourage community involvement in the schools.

One course of action adopted in many school districts has resulted in the sudden nationwide growth of school volunteer programs. According to a survey by the National School Volunteer Program Inc., volunteer programs have mushroomed in schools across the country with the two year period, 1967-1969, witnessing the greatest rate of growth since the start of the first program in 1956. Geographically, New York, California, and Pennsylvania accounted for $61 \%$ of the 163 volunteer programs included in the NSVP survey and were responsible for much of this growth. Most of the volunteer programs were located in cities with populations of 50,000 or more. ${ }^{7}$

${ }^{6}$ Robert W. Blanchard, "Portland Schools For The Seventies," statement at a special meeting of the Portland School Board, Portland, 21 January 1970, p. 2. (Mimeographed.)

Carolyn Kenison, ed., Volunteer Views (New York: National 
Recently the importance of volunteers to education was recognized by the federal government. In December 1969 the first of a new series of newsletters, Volunteers in Education, was published by the U. S. Office of Education for distribution to the hundreds of organized volunteer programs in education throughout the nation. Included in this first edition of the newsletter was a statement by Elinor K. Wolf, Coordinator for Citizen Participation for the U. S. Office of Education, in which she looked at this burgeoning new partnership of school district and interested citizen volunteer as a "minor educational revolution" affecting every service connected with the educational process. ${ }^{8}$

In Portland, by late 1968, volunteer services of various kinds had shown an impact on education programs in the public schools. Throughout the district Parent-Teacher Associations encouraged interested parents to assist teachers in the classroom and on field trips. Tutorial programs sponsored by students at the local colleges had been in operation for several years. In the model schools (schools focusing on compensatory education for culturally disadvantaged students) vol-

School Volunteer Program, Inc., October 1969), p. 4.

8 Elinor K. Wolf, a letter to volunteers in Volunteers in Education (Washington, D. C.: Office of Citizen Participation, U. S. Office of Education, December 1969), p. 2.

9 "Portland Cooperative Volunteer Aicle Program," a proposal presented to the Portland School Board, Portland: 10 February 1969 , p. 1. (Mimeographed.) 
unteer programs involved approximately two hundred individuals, many of whom were recruited through the Greater Portland Council of Churches.

These and other similar programs were excellent and worthwhile individually but did not look at the utilization of volurteer talent on a district-wide basis. In February 1969, with the view that a broader approach was necessary, the Portland School Board approved a proposal for the establishment of Volunteers in Portland Schools, VIPS. This new program was to be jointly sponsored by the Portland Public Schools and the Portland Council PTA to co-ordinate and optimize the volunteers throughout the school district. ${ }^{10}$ The Board directed that VIPS begin as a pilot project in the Cleveland High School district and requested that an evaluation of the project be made prior to further expansion. ${ }^{11}$ Volunteers in Portland Schools and more particularly the VIPS program in the Cleveland High School area are the principal subjects of this thesis. The conception, establishment, and development of this program will be shown along with a collateral look at similar programs throughout the nation. The goals of the program will be identified. The basic assumptions on which VIPS is based will be examined and their validity tested. Finally, conclusions and recommendations will

i $0_{\text {Ibid. }}$

11 Discussion at the Portland School Board meeting, Portland, Oregon, 10 February 1969. 
be presented and discussed. As a postscript, VIPS will be viewed after a growth period of seven years. 


\section{CHAPTER II}

\section{INITIAL PLANNING}

Portland's VIPS program was originally conceived by Duniway Elementary School leaders in the summer of 1968 to meet the needs of their own particular neighborhood school. They soon realized that the Duniway plan had potential for city-wide expansion as a co-ordinated school volunteer program with joint sponsorship by the Portland Public Schools and the Portland Council,P.T.A. a feasible approach. The next step was to hold informal conversations with the chairperson of the Portland School Board and the President of the Portland Council,P.T.A. From these conversations came support and direction for the development of a proposal for a jointly sponsored Portland Volunteer Aide Program. ${ }^{12}$ Six months after the volunteer program was originally conceived, the Portland School Board formally approved the proposal to establish the program. ${ }^{13}$ In so voting, the Board members believed that utilization of school volunteers would be a positive step toward meeting some of the problems in the schools.

12 "Portland Cooperative Volunteer Aide Program, " text of proposal.

13 Discussion at Portland School Board meeting, 10 February 1969. 


\section{DEFINITION OF THE PROBLEM}

The first step in planning Portland's school volunteer program was the recognition and definition of the problem.

The Problem at the Neighborhood School

At Duniway School, where the program was initially conceived, barriers between parents and community blocked a truly effective schoolcommunity relationship. The school patrons in the neighborhood were generally well-educated, opinionated, outspoken, vocal, and to some teachers presented a real or imagined threatening situation. The president of the P.T.A. and the principal of the school believed that the P.T.A. needed to become a more viable and responsive organization serving as a bridge between the neighborhood and the school.

The Duniway community was a middle-uppermiddle class neighborhood noted for its support and regard for education. Its well-educated and informed citizens had often demonstrated a willingness to volunteer time in efforts believed worthwhile. Though they had much talent and energy to contribute to the schools, their services had remained largely untapped.

The District Problem.

In viewing the city as a whole the problems found at Duniway were magnified. Additional problems associated with class load and 
school environment, though not serious at Duniway, were of great concern at the city level.

School-community relations were poor in many areas. Recent elections had shown the beginnings of a taxpayers' revolt. Looking to the 70's the School Board recognized that a substantial outlay of funds would be necessary if a quality education was to be provided by the city schools. Such expenditures would not be possible without citizen support. It was, therefore, important to the Board that every means be used to bring the people closer to their schools to gain greater understanding of school conditions and the problems facing the schools and to involve the public to the greatest extent in the total effort to improve the city's educational system.

In addition to concerns for school-community relations, the Portland schools were faced with problems associated with school environment and class load. In Portland's increasingly complex and impersonal urban society children often lacked a sense of identity. Their need for individual attention was desperate. Teachers, taxed by other matters, found it difficult to provide these children with the help they needed.

The time factor was a constant source of frustration to the average teacher. Classes were large, often with a wide range of student ability. Too much teacher time was usurped by tasks which did not require professional competence and responsibility. Teachers 
were left with insufficient time for class preparation, actual teaching, and individual counseling.

While the P.T.A. had the potential to be a very effective force In the school community, it often appeared sidetracked by trivia. In need of renewed purpose and vigor, the organization was seeking ways to use its influence to improve school-community relations.

\section{Summary of the Problems}

In summary, the following concerns of the school district were believed to have bearing on the consideration of a school volunteer program. There was concern for inadequate school-community relations and a consequent lack of citizen knowledge of school conditions. There was a concern for the failure of the schools to use local resources. There was a concern for overcrowded classrooms with a wide range of pupil ability. There was a concern for teacher frustration over proper use of time. Finally, there was a concern for the ineffective use of P.T.A. in the face of its potential.

\section{BASIC ASSUMPTIONS}

With these problems defined, assumptions were then made to provide a basis for planning the volunteer program. These assumptions were first developed by P.T.A. leaders at Duniway School and continued to be accepted through the various stages of planning. These 
assumptions are outlined below and will be discussed at length in Chapter V.

\section{VIPS BASIC ASSUMPTIONS}

1. The act of volunteering is important to the individual and fills many basic human needs.

2. There is a large supply of untapped human resources in the Portland area willing to enter the schools as volunteers.

3. Teachers can use help in three basic areas. This assistance can be provided by volunteers.

a. Classes are generally too large. Teachers have difficulty giving time to individuals and small groups. Volunteers will provide this additional individual attention.

b. Too much teaching time is consumed by non-teaching tasks. Volunteers can perform such duties and free the teacher to spend more actual teaching time with students.

c. Volunteers with varied backgrounds and interests will provide enrichment opportunities which would otherwise be unavailable to the classroom.

4. School community relations must be improved if the Portland School district is to receive continued financial support from the public. Citizen participation and involvement. as provided in a School Volunteer Program, can help to improve relations between school and community.

\section{GOALS}

With the problems defined and basic assumptions determined, goals for Portland's school volunteer program were established. As set forth in the School Board adopted proposal for development of a 
volunteer program, these goals were:

1. provide volunteer services and talents within the Portland Public Schools to supplement the teacher's effectiveness in the classroom.

2. provide a vehicle for the involvement of interested citizens In the work of the schools, thus improving community relations and support for school programs. ${ }^{14}$

14 "Portland Cooperative Volunteer Aide Program," p. 1. 


\section{CHAPTER III}

\section{STRATEGY}

After the goals of the volunteer program were defined, a strategy for program organization was developed. A committee of representatives from the School District, Portland Council, P.T.A. , and Duniway P.T.A. met to establish the structure and organization of the program. Their work culminated in a proposal for a Portland Cooperative Volunteer Aide Program which was presented to the School Board February $10,1969$.

\section{RESEARCH AND COMPARISONS}

Research into successful established school volunteer programs provided a valuable assistance in the planning stages of Portland's school volunteer program.

\section{National School Volunteer Program, Inc.}

NSVP was organized in April 1964 to help Boards of Education and local citizen groups in the twenty largest cities in the United States, exclusive of New York City, to "establish their own School Volunteer Programs or extend and strengthen existing programs." 15

15 NSVP, Inc. , "General Information Concerning NSVP, Inc." (New York: 1968), p. A-2. (Mimeographed.) 
Upon request, assistance was extended to smaller communities. A Ford Foundation grant to the Public Education Association was the original source of funds for the NSVP. After this grant expired in 1968, NSVP was incorporated as a tax-exempt corporation. Its present purpose is purely advisory for the benefit of school volunteer programs throughout the country. A special emphasis is given to inner city needs. In meeting its goals NSVP Inc. is organized to:

a. Conduct national conferences and regional workshops for the exchange of ideas and materials

b. Serve as a research center and clearing house for materials and studies

c. Research methods of reaching inner city volunteer participation

d. Develop new materials for volunteer organizations

e. Counsel new school volunteer programs on methods of setting up effective programs

f. Bring to small cities the knowledge of the National School Volunteer Program, Inc. and to assist them in establishing their own programs.

g. Supply information to be used in potential teacher education programs. 16

A kit of materials supplied Portland by the NSVP included

${ }^{16}$ Ibid. ,p. A-3. 
general information concerning the administration and supervision of a school volunteer program and the recruitment, orientation, and training of school volunteers. This material proved to be a helpful guide to the establishment of Portland's program.

\section{School Volunteer Programs in Selected Cities}

Other sources of information came from cities which had already experienced successful school volunteer programs. Material from San Francisco, Berkeley, and Los Angeles was the most complete and of the greatest value in determining the organizational structure and procedures to be followed in Portland's volunteer program.

Studies of volunteer programs in other cities revealed that these programs generally began on a very small scale, sometimes just a few people with an idea. Community service oriented organizations such as the Junior League, P.T.A., or National Council for Jewish Women often provided the necessary spark to spearhead a school volunteer plan. As these projects proved successful, they were expanded. In many instances an organization of volunteers was formed. Financial assistance was generally provided by the school district involved. Though a number of volunteer programs were administered directly by the school district, other volunteer organizations preferred to maintain a degree of autonomy.

A pattern repeated in a number of cities provided for a school 
volunteer organization in the form of a nonprofit corporation operating under the auspices of the school district. San Francisco and Berkeley had programs of this nature.

In Los Angeles the program was administered by the school district with policy determined jointly by representatives from the school district, the volunteer organization's board of directors, and from a group called the delegate body which was composed of representatives of sponsoring organizations, representatives of community organizations, school personnel, and volunteer area coordinators. 17

These west coast programs studied were committed to a strong centralized organization. They did not make a serious effort to involve neighborhood people in their own school.

By contrast, in Detroit the entire program operated on a decentralized basis. The program there was "committed to the philosophy that parent loyalty and citizen interest in schools is best built by finding a place for neighborhood parents to 'help create a climate of learning' in their own children's schools. "18 Each Detroit school was allowed as much autonomy as possible within a framework of

17 School Volunteer Program, Office of Urban Affairs, "Procedure Book for Officers and Chairman of the Executive Board, "Los Angeles: Los Angeles City Schools, July 1968), p.5. (Mimeographed.)

${ }^{18}$ Anna W. M. Wolf and Adele B. Tunick, Reaching the Neighborhood Parent (New York: National School Volunteer Program of the Public Education Association, 1966), p. 7. 
district-wide policies.

Philadelphia was another city which emphasized a neighborhood approach. "We need you to help us improve your children's school performance" is the message which was brought to the people. 19

\section{STRUCTURE OF THE PORTLAND PROGRAM}

One of the basic decisions necessary in determining Portland's program centered on the question of centralization. School principals who were consulted favored a decentralized plan as did the P.T.A. leaders from Duniway School. Representatives from the city P.T.A. organization believed in a more centralized control closely tied to the city P.T.A. structure. As Portland's plan finally evolved, the emphasis was on the neighborhood development of the school volunteer program. According to the plan adopted by the Portland School Board, the school volunteer program was structured along a three tiered, pyramid form of organization with a coordinator at each level.

\section{Levels of Organization}

At the bottom of this pyramid were the nelghborhood schools. They were responsible for developing their individual volunteer programs to meet their own particular needs. Autonomy was allowed within 
a framework of district wide policy. Coordinators at the individual school level were jointly selected by school principal and P.T.A. president. The principal criteria for selection were knowledge of community, ability to reach people, and commitment to the volunteer program. ${ }^{20}$ Though helpful, P.T.A. membership was not a prerequisite for selection. These coordinators were charged with the responsibilities of volunteer recruitment, processing of requests for volunteer service, and follow-up evaluation of volunteer assistance.

The second level of coordination was at the P.T.A. section level which corresponded to the area of a single high school and its feeder schools. By utilizing the section, neighboring schools worked cooperatively together as part of a larger whole. The section coordinator, selected jointly by P.T.A. and school district, assisted with volunteer placement by looking to neighboring schools when volunteer placement could not be completed by an individual school.

Though much of the actual operation of the program was delegated to the local school and section, overall responsibility for the program was centrally maintained by a director hired by the school district. Duties of the director included the recruitment of volunteers from community organizations and businesses, public relations through newsletter and other promotional media, assistance to schools starting 20 "Portland Cooperative Volunteer Aide Program," p. 4. 
volunteer programs, presentation of orientation and training sessions, and the establishment of a liaison to various departments of the school system.

Policy for the program was made by an advisory group composed of a representative from each of the sponsoring organizations, the Portland Public Schools and the Portland Council P.T.A., as well as a third member from the ranks of school volunteers.

Organizational Chart. Figure 1 depicts the organizational structure of VIPS as outlined in this chapter.

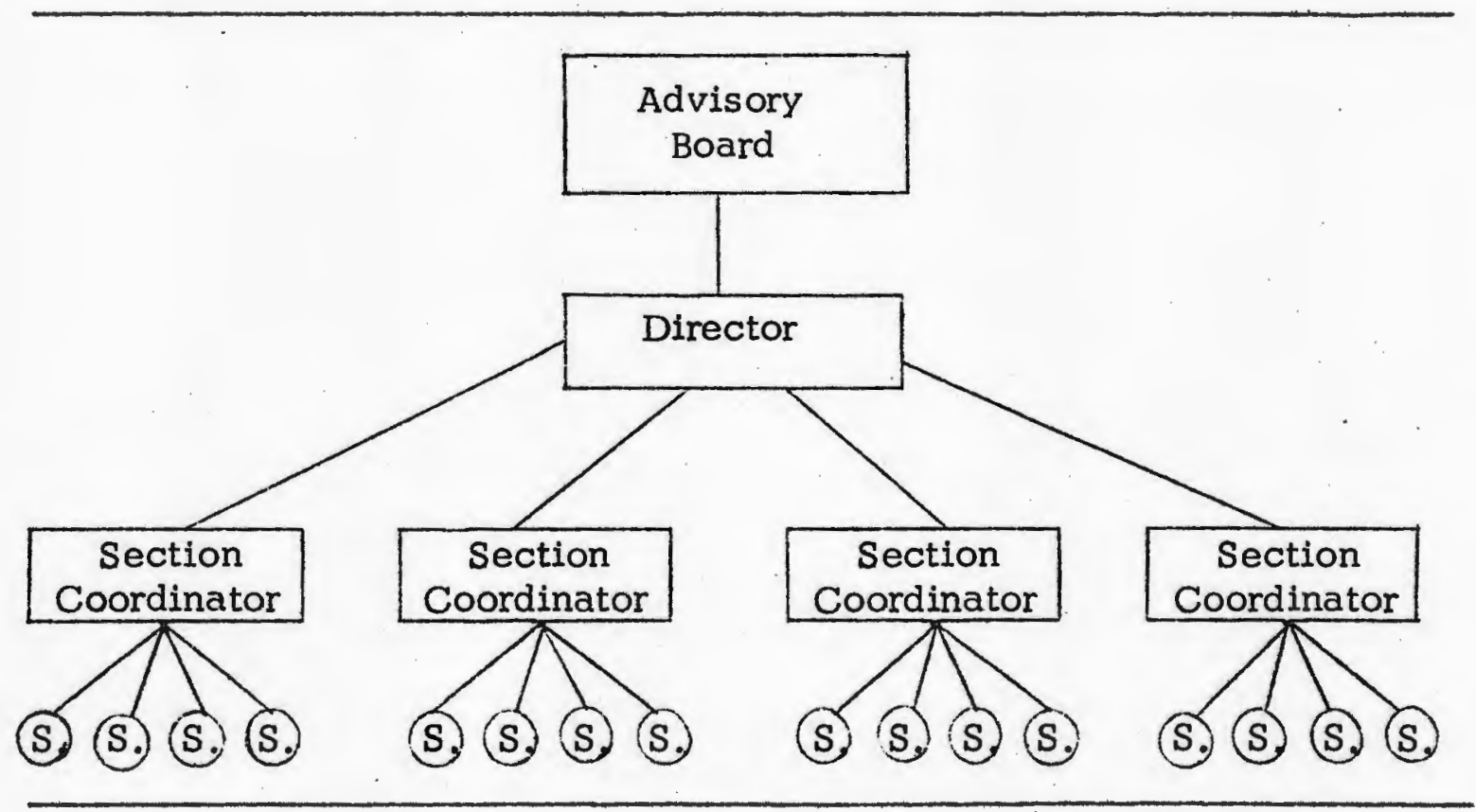

Figure 1. Proposed organizational structure: Volunteers in Portland Schools, February 1969. S. denotes participating school. 
III. GUIDELINES

In addition to the structure outlined, certain guidelines or policy statements were agreed upon and included in the proposal for the Portland School Volunteer Aide Program. The guidelines are listed below:

1. Volunteer aides will not be used to replace teachers or regular paid aides. Their function shall be to supplement the work of the regular school staff. The teacher shall always retain ultimate responsibility for his own educational programs.

2. Volunteers shall be used only by those persons who request such services. In no case will a volunteer be assigned to a teacher who does not indicate an interest in such services.

3. Volunteers shall have an application on file in the central office prior to their performance of any services. Included shall be a TB card indicating negative results.

4. All volunteers shall be subject to an initial screening and follow-up evaluation.

5. Volunteers shall participate in orientation sessions and,when needed, specialized training sessions. ${ }^{21}$

21 Ibid. 
IV. INITIATION OF THE PROGRAM

In adopting the proposal for a Portland Cooperative Volunteer Aide Program in February 1969, the School Board directed that the volunteer program be initiated as a pilot project in an area equivalent to a high school district. This restriction on the initial size of the program was proposed "to insure that operational procedures and facilities" would be "adequate to handle the volume of work." 22 Since the concept for the school volunteer program initiated at Duniway school, the Board designated the Cleveland High School district, which includes the Duniway neighborhood, to be the pilot project area.

\section{EVALUATION OF THE PILOT PROJECT}

Additionally, the Board recommended that evaluative processes be employed to "assist in judging whether or not procedures" in the pllot project were "sufficiently efficient to provide:

1. timely follow-up on each new application

2. meaningful evaluation of each volunteer's services

3. up-to-date volunteer records

4. efficient assignment of volunteers " 23

Expansion of the program was dependent on a positive evalu-

$$
\begin{aligned}
& 22 \text { Ibid. , p. } 5 \\
& 23 \text { Ibid. , p. } 6 .
\end{aligned}
$$


ation with a "sequence of evaluative processes" employed to "parallel the expansion of the project within the school district. " 24

\section{SUMMARY}

A period of approximately nine months elapsed between the time that a coordinated school volunteer program was conceived and the time that the School Board recommended that the program become district-wide with a paid coordinator. The events of this period were as follows:

1. In September 1968 the concept of the program was presented to the Executive Board, Portland Council,F.T.A.

2. From October 1968 to February 1969 a committee of representatives from the P.T.A. and school district prepared a draft of a proposal for a Portland Cooperative Volunteer Aide Program.

3. February 10, 1969 the School Board approved the proposal and established the program known as Volunteers in Portland Schools, VIPS. The Cleveland High School district was designated as a pilot project area.

4. February 17,1969 , a coordinator for the pilot project was selected and the pilot project commenced.

5. From May to June 1969, the pilot project was evaluated by the ${ }^{24}$ Ibid. . p. 6. 
office of the Assistant Superintendent of Schools for Curriculum. 6. June 23, 1969, the School Board approved a recommendation by the Assistant Superintendent to expand VIPS to a city wide program with a paid director. 


\section{CHAPTER IV}

\section{OPERATION OF THE PILOT PROJECT}

Discussion of the early operation of the VIPS program must necessarily focus on the pilot project. The procedures initially developed in this early stage were generally retained when the program was expanded.

The pilot area chosen by the School Board included Cleveland High School and its ten feeder elementary schools. ${ }^{25}$ The location of Duniway School as one of these feeder schools was the determining factor in the selection of this area. Since the Duniway P.T.A. had provided the impetus and primary interest for a volunteer program, it was only natural that it should be directly involved in establishing the pilot program.

One week after the School Board established Volunteers in Portland Schools in February 1969, a meeting of Cleveland area principals and P.T.A. presidents was called jointly by the Assistant Superintendent of Schools for Curriculum and the President, Portland Council, P.T.A. Information on the goals and strategy of the volunteer program was distributed, the role of the participating schools was discussed,

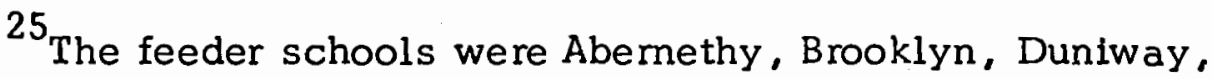
Edwards, Grout, Hosford, Lewis, Llewellyn, Sellwood, and Woodstock. 
and participation in the pilot program was encouraged. At the conclusion of this meeting a coordinator was appointed to administer the Cleveland area pilot project. This action was taken in accordance with the guidelines set forth in the School Board adopted VIPS program.

\section{PHILOSOPHY OF THE PILOT PROJECT}

The coordinator immediately arranged to meet with her Area Director for Elementary Education and the P.T.A. Vice President for the Cleveland district. With these representatives from the two VIPS sponsoring organizations a philosophy for the pilot project was mutually determined.

It was believed that the pilot project should be allowed a great deal of freedom to develop its program. Basic policies and the general framework of operation as set forth in the proposal adopted by the School Board would be followed. It was agreed that success in the program would depend largely on its acceptance, first by the principal, and then by the staff, of a participating school. It was recognized that each school and its neighboring community was unique and that this uniqueness should be preserved in establishing each school's plan for using volunteers. A volunteer program of the community, not in the community, was a primary goal of the pilot project. 
II. DEVELOPMENT OF MATERIALS AND OPERATIONAL PROCEDURES

In planning the pilot project, imrnediate priority was given to the development of materials necessary for operation of the program. This was expedited by the fact that a parent-teacher committee from Duniway School had already been working to draw up a workable volunteer plan for their own school. The pilot project benefited from this research and study by incorporating the Duniway developed material into its overall plan.

Within a few days after the pilot project began the procedures for its operation were defined and the necessary materials were printed. They were flexible and subject to evaluation and change as warranted. Included among these materials were a volunteer request form for classroom he $1 \mathrm{p}$, a request form for resource assistance, a personal interview form, a questionnaire on community resources, and a VIPS brochure. 26

\section{THE PROGRAM IN THE SCHOOLS}

The Cleveland area schools were invited to participate in the VIPS program. Every effort was made to minimize any feeling of obligation on the part of the individual school to develop a VIPS program just 26 These documents may be found in Appendix $A$. 
because it happened to be located in the pilot area.

The project coordinator met with the principal and P.T.A. president, when possible, to familiarize them with the VIPS program and to offer any needed assistance in establishing a volunteer program . Goals and procedures of the program were explained. The school was invited to use and test the prepared materials .

As each school coordinator was selected, the project coordinator met with her individually to help with the step-by-step establishment of her school's program.

A close working relationship with the faculty of each school was encouraged. Recruitment and promotion for the program were developed by each school on an individual basis. All schools agreed to use a VIPS brochure prepared by the School District Office of Public Information in consultation with principals from three participating schools.

It is interesting to note the different approaches used by the schools to establish their volunteer programs. Figure 2, page 28 , illustrates this individuality of participating schools.

During the initial period of the pilot project one hundred twenty-five people volunteered to participate in VIPS. Approximately one-third of this total number was willing to serve in any school within the project area and $10 \%$ were willing to serve anywhere within the 


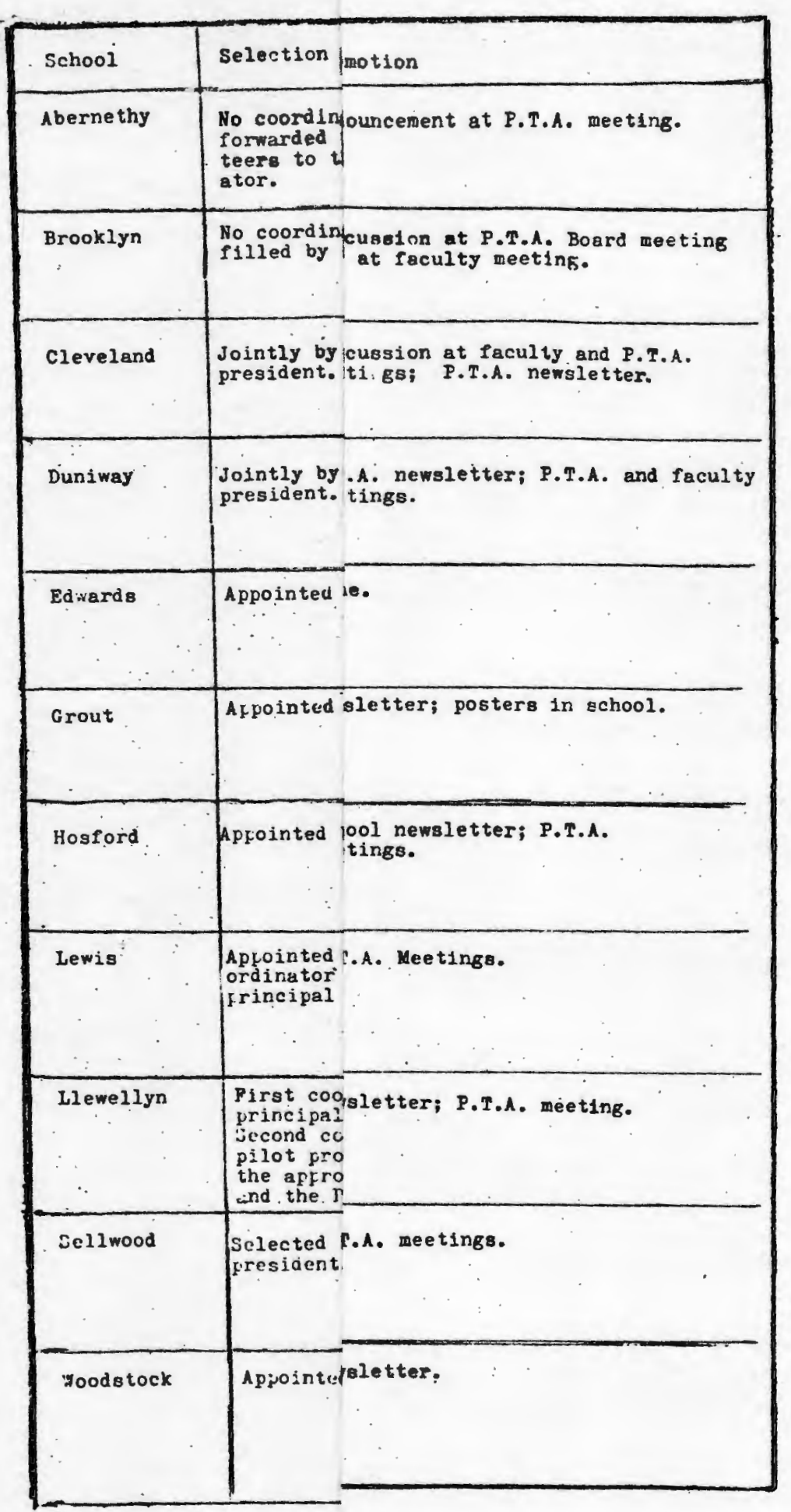


school district. ${ }^{27}$ As shown by these figures the volunteers 'primary interest was with their own schools.

During the first three months of operation, forty-five teacher requests for VIPS volunteers were received. 28 This figure represented participation by nine of the eleven schools in the project. Three-fourths of the requests were filled locally and one-fourth was filled by the pilot project coordinator when local placement was not possible. The nature of the requests varied widely. Included were requests for tutoring and working with small groups, setting up a science fair, matting an art display, doing research, maintaining a picture file, and chaperoning a field trip. Resource volunteers provided information on the medical profession, the zoo, rocks and minerals, birds, Mexico, and Japan.

\section{EVALUATION OF THE PILOT PROJECT}

The VIPS proposal approved by the School Board on February 10, 1969 requested that an evaluation of the pilot project be made prior to further expansion of the program.

A progress report of the program was written and presented to

27 Mary B . Norville, "Volunteers in Portland Schools (VIPS), Cleveland Area Pilot Project," (Portland, 12 June, 1969), p. 4. (Typewritten.) ${ }^{28}$ Ibid 
the School Board at its June 23, 1969 meeting. The questions which the report sought to answer were:

1. Do procedures provide timely follow-up on each new applicant?

2. Are volunteers being evaluated, both to best utilize their talents and to insure the appropriateness of their contact with students?

3. Are records being maintained of volunteers, their talents, skills, and assignment preferences?

4. Are volunteers being usefully assigned in the schools ? ${ }^{29}$ Answers to these specific questions posed in the report were determined by responses to survey questionnaires sent to teachers, principals, coordinators, and volunteers participating in the pilot program. Replies to questionnaires indicated that:

1. There was a wide latitude on follow-up of volunteer applications.

2. Evaluation was on a very informal basis.

3. Records were maintained by the coordinator of the individual schools with all principals having access to this information.

4. Principals and teachers indicated approval of the program.

5. Volunteers generally enjoyed their work, but on occasion, felt

29 "Volunteers in Portland Schools Progress Report" (Portland: Portland Public Schools, 19 June 1969), p. 1. (Mimeographed.) 
their abilities were not being used as fully as possible.

From this survey it appeared that the program was loosely structured and quite flexible and that it was gaining support from professionals and volunteers alike.

In addition to the progress report, the coordinator of the pllot project wrote a report reflecting the thinking of the school coordinators as set forth at a May 28 meeting to informally evaluate the pilot program. According to this report, the coordinators believed that VIPS was a worthwhile program. They were enthusiastic about their schools' participation in the pilot project. Coordinators stated that organizational procedures used had worked reasonably well, but they believed that the role of the local school coordinator in placement of volunteers should be more explicitly outlined in written material. Recommendations for specific changes in application forms and volunteer questionnaires were given. The value of the brochure as a neighborhood recruiting device was questioned. It was believed that brochure distribution to community organizations would be of 31

greater importance.

The coordinators firmly believed that the emphasis of the VIPS structure should be at the local school level. They recommended that

$30_{\text {Ibid. , p. } 7 .}$

\section{1}

Norville, "Volunteers in Portland Schools (VIPS), Cleveland Area Pilot Project," p. 7. 
the growth of the VIPS program be "natural and easy." 32 There appeared to be a concern among the coordinators over centralization of the program. However, the coordinators also realized that a central office could and should perform valuable services such as those listed in Chapter III. To quote one of the coordinators, "The need for the central office should grow out of the program. It should not create the program." 33

\section{EXPANSION OF THE PROGRAM}

On June 23, 1969 the Portland School Board voted to expand VIPS on the recommendation of the assistant Superintendent of Schools who asked that "the district help those schools which wanted to start programs." He further recommended that the Portland Public Schools provide certain district-wide services and hire a part-time director for this purpose. 34

With the expansion of VIPS, the pilot project was officially ended. However, the schools in the Cleveland area continued to work cooperatively together. Five of the elementary schools from the project developed a strong sense of teamwork, helping each other with recruit-

32

Ibid.

33

Ibid.

${ }^{34}$ Discussion at the Portland School Board meeting, 23 June 1969 . 
ment and placement of volunteers. 35

The Cleveland area was the only district in the city with a volunteer program large enough to warrant a coordinator at the high school level in the school year 1969-1970. Because of this, it was uniquely qualified to be the subject of further research to test the validity of the basic assumptions of the VIPS program. The findings of this research are discussed in the following chapter.

${ }^{35}$ The five schools were Duniway, Grout, Llewellyn, Sellwood, and Woodstock. 


\section{CHAPTER V}

\section{EXAMINATION AND EVALUATION}

Basic assumptions for the development of Volunteers in Portland Schools were listed in Chapter II, page 11. In this chapter these basic assumptions will be examined and their validity tested in light of experiences with volunteers here in Portland as well as in other cities. This testing took place in the winter and spring of 1970 and focused on the Cleveland High School area. The VIPS program had been in operation there for approximately one year.

\section{BASIC ASSUMPTION \#I}

The act of volunteering is important to the individual and fills many basic needs.

Assumption \#l deals with the act of volunteering as it relates to the basic human needs of the volunteer. This subject was discussed very completely by Dr. Eva Schindler-Rainman at an October 1969 Workshop on Volunteers which was jointly sponsored by the Oregon Association of Volunteer Leaders and the Junior League of Portland. Dr. Rainman, a sociologist and consultant to various school districts, organizations, and businesses, is recognized as an expert on the volunteer. At the workshop, Dr. Rainman stressed the importance of understanding that volunteering is a two way service with the volunteer 
not only giving needed assistance, but also receiving in return satisfaction for some basic human needs. Dr. Rainman stated that recognition of these needs was important to keep in mind, for they have "much to do with questions of recruitment, of keeping, and of motivating volunteers" ${ }^{36}$ and must be met if a volunteer program is to be successful.

\section{Basic Needs as Listed by Dr. Rainman}

As discussed by Dr. Rainman, there are thirteen basic needs which have a direct bearing on a volunteer program. These needs are listed below.

1. The Need to Belong: In today's increasingly impersonal society with our greater mobility and more fragmented families, the need to belong somewhere in something valued by the volunteer is very important.

2. The Need to be Recognized: Recognition for giving service is important to an individual for development of a positive self-image.

3. The Need to Learn: Man has a basic need to learn. School volunteers often serve because they want to find out what children are learning in the schools and how the schools function. They want to understand the younger generation better.

${ }^{36}$ Dr. Eva Schindler-Rainman, "The New Day of the Volunteer," transcript from a speech delivered at a Workshop on Volunteers sponsored by the Junior League of Portland, Portland, Oregon, 13 October 1969, p. 4. (Mimeographed.) 
4. The Need to Give: Human beings have a need to give of themselves, their ideas, and their resources.

5. The Need to be Creative: Creative in this sense does not mean something original, but rather a new combination of old and new ideas.

6. The Need to be Powerful: Volunteering often allows for a positive way to use power by influencing others.

7. The Need to be Hopeful: Volunteering provides the individual with an event to look forward to. An exciting experience may be a strong motivating factor in recruiting and retaining volunteers.

8. The Need to Have Fun: Volunteering can be fun. It all depends on the volunteer's attitude toward it.

9. The Need to Succeed: The need to succeed and the need to be recognized are closely allied.

10. The Need to Have a Part in Problem Solving: The volunteer wants to participate in problem solving areas that directly effect him.

11. The Need to Make Decisions: Closely allied with problem solving, decision making builds the volunteer's feeling of importance and develops a stronger feeling of involvement and purpose.

12. The Need to be Considered a Dignified, Individual and Particular Human Being: The volunteer needs to be viewed as an individual person with individual needs and individual resources. People 
do not want to be a number or just another volunteer, but rather a particular volunteer.

13. The Need to Make a Difference: The volunteer must feel that he has made a positive contribution and that his efforts have made a difference. 37

\section{Evidence of Meeting these Basic Needs}

School volunteer programs across the country are satisfying the basic human needs as just outlined. In relating experiences of retired persons serving in education, the words "tremendous satisfaction," "meaningful," "productive," and "recognition" are used to describe what volunteer service means to them. Howard Bede, a retired advertizing executive and leader in a nationwide program to set up Volunteer Resource Pools, states that volunteer work is "the finest bit of therapy possible. You get no money but lots of fun and good health . "38

As determined by a 1967 survey, reasons for volunteering were summarized as the achievement of self-satisfaction without thought of personal gain. In this survey, conducted in South Carolina, volunteers throughout the state were contacted. They were generally from upper-

37

Ibid. , pp. 4-6.

38 "Profile," Volunteers in Education (Washington, D. C . : Office of Citizen Participation, U.S. Office of Education, December 1969), p. 3. 
middle and upper income levels with a background and habit of volunteer service. Ninety-six percent of those surveyed cited "a rewarding relationship with those served" as a major reason for their volunteer service. Other significant reasons included "love of people" and "interesting work" both with an $82 \%$ response; "duty," 76\%; and "like to feel needed," $64 \% .^{39}$

In New York City the community-based agency, Mobilization for Youth, Inc., found the use of school volunteers to benefit the tutors as well as the pupils. In their program, eleventh and twelfth grade high school students worked with disadvantaged grade school children on a one-to-one basis. The improved progress of the pupils in this program gave the tutors a feeling of accomplishment which often motivated them toward their own improved academic achievement. ${ }^{40}$ Similar results have been noticed across the nation in school-based programs where older children have worked with younger students.

Rewards to school volunteers in programs that focus on parents, particularly mothers, as the source of their volunteer pool are an

${ }^{39}$ Guion Griffis Johnson, Volunteers in Community Services (Chapel Hill, North Carolina: The North Carolina Council of Women's Organizations, Inc., 1967), p. 72.

40 "Non Professionals Tutor Disadvantaged," Volunteer Views, (New York: National School Volunteer Program, Inc., October 1969), p. 2 . 
increase in "learning about self, children, and interworking of mind and heart." 41 With a greater amount of leisure time for many housewives, volunteering in the schools filled a personal need in which a view of self demands an "enhanced role in society beyond household function." 42

Locally, a June 1969 survey of Portland's VIPS pilot project indicated that volunteers enjoyed their duties. In this survey, questionnaires were sent by the Portland School District to fifty VIPS volunteers selected at random from the total volunteer population in the pllot project area. Twenty-six questionnaires were returned. In the survey volunteers were asked to respond to the following questions:

1. How did you first hear of the VIPS program?

2. Approximately how much time elapsed from the time you filed an indication of interest card for the VIPS program until you were contacted by a VIPS representative?

3. Do you think your service has been adequately used?

41 James Nathan Miller, "Robert Finds A Friend, "The PTA Magazine, June 1966, p. 6.

${ }^{42}$ Thelma G. Wolman and Florence D. Shelley, "Volunteers in the Public School: Bonus or Burden?" National Elementary Principal. May 1967, p. 35. 
4. How many days have you served as a volunteer?

5. Would you be interested in participating in orientation sessions or classes that would assist you in working in the schools? 43 Space was provided for all respondents to comment on the VIPS program. Among comments in the survey were the following: "I enjoyed giving my time to this school"; "It was interesting"; and "The small assistance I am able to give is truly enjoyable.. . not only does the school benefit from this program but the volunteer as well." 44 There were no negative comments. Additionally, in casual conversations with VIPS volunteers, a definite feeling of accomplishment was clear. The volunteers felt good about themselves and their work in the schools. Admittedly these are subjective impressions and cannot be compared to any control population, but they do communicate the general sense that Portland VIPS volunteers had a pleasurable and rewarding experience.

\section{BASIC ASSUMPTION \#2}

There is a large supply of untapped human resources in the Portland area willing to enter the schools as volunteers.

43 "Volunteers in Portland Schools Progress Report," p. 7. ${ }^{44}$ Ibid., pp. 10-11. 
In the pilot project,almost all teacher requests for volunteer assistance were filled fairly easily. The total number of volunteers available was certainly considerably greater than the number of requests. The major difficulty encountered was the utilization of volunteers effectively.

Experiences of school volunteers in other cities indicate that there is a wealth of potential volunteer resources available. Parents and the community at large, colleges, high schools, retiree groups, civic organizations, businesses, and industry are all a potential source of volunteers. There is apparently no question that the necessary human resources for a school volunteer program are present. The concern, rather, is in successfully tapping these resources. This subject will be discussed in the following chapter in connection with recommendations for recruitment.

\section{BASIC ASSUMPTION \#3}

Teachers can use help in three basic areas. This assistance can be provided by volunteers.

a. Classes are generally too large. Teachers have difficulty giving time to individuals and small groups. Volunteers will provide this additional attention.

b. Too much teaching time is consumed by non-teaching tasks . Volunteers can perform such duties and free the teacher to spend more actual teaching time with students.

c. Volunteers with varied background and interests will provide enrichment opportunities which would otherwise be unavailable to the classroom. 
Basic assumption \#3 deals with the three basic areas in which teachers can use assistance provided by volunteers. Each one of these areas will be discussed.

\section{Generally Large Classes}

Class size in Portland was the subject of a September 1969 report by the Administrative Research Department of the Portland Public Schools. This report showed that while progress had been made in a six year period in reducing the number of overcrowded classrooms in the city, there were still many overcrowded classrooms. Using a standard of twenty-five for grades one to six and twenty-eight for grades seven to eight the report indicated $72.2 \%$ of all classes were still in excess of these standards. 45

Large classes were also cited in a September 1969 report of the Portland Association of Teachers, Teacher Education and Professional Standards Commission. In this report a survey was made of Portland teachers to determine barriers to effective teaching. One thousand five hundred forty-two Portland teachers responded to the survey. "Large class size" ranked second as a major barrier to effective teaching. 46 From these two sources it is clear that, in Portland,classes

${ }^{45}$ Elementary School Enrollment Report as of September 26, 1969 (Portland, Oregon: Administrative Research Department, Portland Public Schools, January 1970), p. 1. (Mimeographed.) 
were viewed as too large.

In the P.A.T. report other problems associated with class

load concerned teachers. Ranking number one as a major barrier to effective teaching was the complaint that teachers did not have "enough time to deal with individual differences." A "pupil ability range too wide for effective teaching/learning" was ranked number four in the same survey. 47

If these statements by Portland teachers are accepted as true, the question arises as to effective means to combat the situation. Volunteers in Portland Schools may be looked to as a partial solution to the problem.

Experiences in other cities document this view. Teachers across the nation feel a frustration at not being able to give children the individual attention they feel necessary. This need by students for individual attention, together with a willingness by volunteers to give it, has produced many successful volunteer programs.

As compared to paid aides, the volunteer's work is more often child centered. ${ }^{48}$ The effectiveness of volunteers working with indi-

Portland Association of Teachers, Teacher Education and Professional Standards Committee (Portland, Oregon: September 1969), p. 8.

${ }^{47}$ Ibid.

48 Mary D. Shipp, "Teacher Aides: A Survey," The National Elementary Principal, May 1967, p. 32. 
viduals or small groups has had a psychological as well as academic outcome. It has been noted that children often gain a better view of self and become more confident individuals when they have someone special helping them. ${ }^{49}$ Performance may also improve. As stated in a recent article in Education Leadership. "When a child has confidence in his relationship with a 'special' adult who is a sincere human being, he may perform beyond expectation." 50

A 1967 study of a corrected reading program staffed by volunteers for the Indianapolis archdiocese showed significant gains made by pupils. These students met in small groups of four to six members with a volunteer tutor. Results of the survey showed that $85 \%$ of the pupils made positive gains in reading ability as measured by pretest and post test scores of nationally known standardized tests. More importantly, however, were the positive attitudinal changes as reported by parents and teachers. 51

Programs such as this show the gains that may be made by effective use of volunteers working with children either individually or

${ }^{49}$ Florence C. Weed, "It Worked for Me," Grade Teacher, March 1969, p. 30.

${ }^{50}$ Joe A. Richardson and Janet Burgoon, "A Volunteer Talent Pool and the Public School, "Educational Leadership 26 (April 1969): 709 .

${ }^{51}$ Mary W. Cunningham, "A Corrected Reading Program Using Volunteer Help," Catholic School Journal 67 (March 1967): 70. 
in small groups. To illustrate this point further, the comments of a Portland elementary school principal are pertinent. He related the story of two children, a boy and a girl, who were withdrawn and unresponsive prior to receiving help from their volunteer tutor. For both the se children a marked change in attitude was shown after only a few months tutorial help. Both children then appeared more willing to try and to carry through their work independently. 52

\section{Teaching Time Consumed by Non-Teaching Tasks}

A common complaint among teachers is that they are trained to teach yet spend too much time at non-teaching tasks. A study sponsored by the Ford Foundation for the Bay City, Michigan Public Schools revealed that twenty-one to sixty-nine percent of a teacher's time was spent on non-essential tasks. ${ }^{53}$ There is every reason to believe that a similar situation is found in Portland and elsewhere in the United States.

An interesting study of twenty-five Michigan public schools showed the use of aides changed the pattern of the use of teacher energy. For this study, teacher activity was actually measured by a stop watch both before and after use of aides was begun. It was noted

52 Interview with Lloyd Rainwater, Principal of Duniway School, Portland, Oregon: 7 March 1970.

53 Sister Phyliss Boudreau, "Teacher Aides," National Catholic Educational Association Bulletin. (August, 1967): 149. 
that in the two year period in which aides were used, the following nonteaching tasks consumed a significantly smaller amount of teacher time: correction of papers decreased $89 \%$; enforcement of discipline decreased $36 \%$; attendance taking decreased $76 \%$; monitoring written lessons decreased $83 \%$; preparing reports decreased $25 \%$; and supervision of children moving from class to class decreased $61 \%$. Teachers were able to increase their preparation time by $105 \%$, the ir recitation time by $57 \%$, and their preparation of home work assignments by $20 \%$. In addition they were able to move from desk to desk giving individual help $27 \%$ more than before. ${ }^{54}$ While this study dealt with paid fulltime aides, there is every reason to believe that regular volunteer help could provide similar relief, though to a lesser degree.

In Syracuse, a study of volunteers working on a regular basis with exceptional children showed that teachers were freed to do "more creative planning, provide more materials, give more individual attention to the children, and in general increase the quality of their instruction." 55

In these two studies it was shown that by relieving teachers

54 U. S. Department of Health, Education, and Welfare, Staffing for Better Schools, by Malcolm Provus, et al. (Washington, D. C.: Government Printing Office, 1967), p. 14.

${ }^{55}$ William M. Cruickshank and Norris G. Haring, A Demonstration: Assistance for Teachers of Exceptional Children (Syracuse: Syracuse University Press, 1957), p. 37. 
of some of their non-teaching tasks, their time may be used more profitably in areas for which they are professionally trained and needed.

\section{Volunteers Provide Enrichment}

Resource programs are an integral part of many school volunteer projects. In Washington, D. C., for example, volunteers sign up for a semester to provide supplementary specialized instruction for the regular classroom curriculum and in so doing bring added realism and excitement to the subject matter. 56

In Berkeley, California the Community Resource Service is part of the district's School Resource Volunteer Program. In that city a yearly talent search is conducted to find people in the community willing to give time to the schools as resource volunteers. 57 A university town, Berkeley is particularly suited to developing a resource pool of volunteers with a wide variety of expertise.

In San Francisco resource services are patterned after Berkeley's program with the fields of art, music and drama especially served in the talent search. 58

56 Jerome Bahr, "Non-Professional Teachers Enliven the Subject Matter," Clearing House 43 (April 1969): 494.

57 "View II--Volunteers in Education Workshops II," workshop proceedings at the College of San Mateo, San Mateo, California, 20 April 1968, p. 16. (Mimeographed.)

${ }^{58}$ Ibid . . p. 19. 
It may be argued that enrichment programs such as these help to stimulate a child's creative efforts. ${ }^{59}$ They build positive attitudes toward the vast interesting world of adults. ${ }^{60}$ They make possible a different type of curriculum which opens doors to a wider world, "one which values emotions more, which values minds more, which values conscience more." 61

Summary: Volunteer Assistance in Portland, January to June 1970

To determine if assistance for teachers can be provided by volunteers as outlined in Assumption \#3, page 40, a brief survey was made in the Cleveland High School area in the winter and spring,1970. Volunteers working in particlpating schools were asked to provide information on the nature of their volunteer assignment, number of hours of volunteer work, grade level, and school for the weeks of January 12 , February 23, April 13, and June 1. ${ }^{62}$ Responses to the survey were

59 Pauline I. Jensen, "In Minneapolis: Hundreds of Volunteers Help Teachers Teach Better," Grade Teacher, September 1967, p. 92.

60 Julie Carlson, "If You're On Your Own . . When to Find Resource People and How to Use Them," Grade Teacher, September 1967, p. 92 .

${ }^{61}$ Beatrice C. Boyles, "New Branches Grow on the Educational Family Tree," National Elementary Principal, May 1967, p. 38.

62 This information was indicated by a volunteer on the reply card found in Appendix B. 
divided into teaching tasks, non-teaching tasks, and resource. 63 The results of the survey showed little or no use of volunteers for resource. During the first two test periods non-teaching tasks accounted for the greatest percentage of volunteer time. This was directly attributable to heavy use of volunteers for a data processing project at Cleveland High School. During the last two test periods, with the demand from the high school reduced, approximately twice as many hours of volunteer service were devoted to teaching tasks as to non-teaching tasks. While the total number of hours was not large, it indicated a beginning acceptance by teachers of the volunteer in the classroom.

\section{BASIC ASSUMPTION \#4}

"School Community relations must be improved if the Portland School District is to receive continued financial support from the public. Citizen participation and involvement, as provided in a School Volunteer Program, can help to improve relations between school and community."

Obtaining adequate financial support is a serious problem for school districts across the nation. Until recently Portland has had an enviable record of public support. The district's major source of school revenue has been the property tax with a statutory limitation of a $6 \%$ increase per year. To receive additional funds, either through an 
TABLE I

SURVEY OF VOLUNTEER ASSIGNMENTS IN THE CLEVELAND HIGH SCHOOL AREA WINTER AND SPRING 1970

\begin{tabular}{|c|c|c|c|c|}
\hline & January & February & April & June \\
\hline $\begin{array}{l}\text { Number of survey cards } \\
\text { sent }\end{array}$ & 59 & 72 & 64 & 49 \\
\hline Number of responses & 54 & 63 & 49 & 36 \\
\hline $\begin{array}{l}\text { Percentage of cards } \\
\text { returned }\end{array}$ & $91.73 \%$ & $87.5 \%$ & $76.56 \%$ & $73.47 \%$ \\
\hline $\begin{array}{l}\text { Number of responding } \\
\text { volunteers who did not } \\
\text { have assignments }\end{array}$ & 1 & 16 & 9 & 8 \\
\hline $\begin{array}{l}\text { Average number of hours } \\
\text { worked per volunteer }\end{array}$ & 3.83 & 3.46 & 2.66 & 2.43 \\
\hline
\end{tabular}


TABLE II

VOLUNTEER ASSIGNMENTS FOR TEACHING TASKS IN THE CLEVELAND HIGH SCHOOL AREA

WINTER AND SPRING 1970

\begin{tabular}{|c|c|c|c|c|}
\hline Task & $\begin{array}{l}\text { Hours of Work; } \\
\text { Week of Janu- } \\
\text { ary } 12,1970\end{array}$ & $\begin{array}{l}\text { Hours of Work; } \\
\text { Week of Febru- } \\
\text { ary } 23,1970\end{array}$ & $\begin{array}{l}\text { Hours of Work; } \\
\text { meek of April } \\
13,1970\end{array}$ & $\begin{array}{l}\text { Hours of Work; } \\
\text { Week of June I, } \\
1970\end{array}$ \\
\hline Tutoring: one-to-one & 62.75 & 54.25 & 31.75 & 30.00 \\
\hline Tutoring: small groups & 12.50 & 4.50 & 20.00 & 10.00 \\
\hline General classroom & 7.50 & 8.50 & 8.50 & 4.50 \\
\hline Special class projects & 10.50 & 9.5 & 10.50 & 1.50 \\
\hline Total hours & 92.25 & 76.75 & 70.75 & 46.00 \\
\hline $\begin{array}{l}\text { Teaching tasks as a per- } \\
\text { centage of all tasks per- } \\
\text { formed during each } \\
\text { survey period }\end{array}$ & $47.9 \%$ & $46.9 \%$ & $69.7 \%$ & $66.9 \%$ \\
\hline
\end{tabular}


TABLE III

VOLUNTEER ASSIGNMENTS FOR NON-TEACHING TASKS IN THE CLEVELAND

HIGH SCHOOL AREA

WINTER AND SPRING 1970

\begin{tabular}{|c|c|c|c|c|}
\hline Task & $\begin{array}{l}\text { Hours of York; } \\
\text { Week of Janu- } \\
\text { ary } 12,1970\end{array}$ & $\begin{array}{l}\text { Hours of Work; } \\
\text { Week of Febru- } \\
\text { ary } 23,1970 \\
\end{array}$ & $\begin{array}{l}\text { Hours of Work; } \\
\text { Week of April } \\
13,1970\end{array}$ & $\begin{array}{l}\text { Hours of Work; } \\
\text { Peek of June } 1 \text {, } \\
2970\end{array}$ \\
\hline Driver & $2: 00$ & 2.50 & & \\
\hline Language $1 \mathrm{ab}$ & 6.00 & 9.00 & & \\
\hline Office work & 14.25 & 53.50 & 23.25 & 8.00 \\
\hline Library & 17.25 & 11.25 & 5.00 & 7.00 \\
\hline Selling lunch.tickets & 5.50 & 5.50 & 6.00 & 4.75 \\
\hline Reading papers & & 4.00 & & \\
\hline Printing class paper & & & 1.50 & \\
\hline $\begin{array}{l}\text { Preparing teacher } \\
\text { materials }\end{array}$ & & & & 3.00 \\
\hline Data processing & 44.00 & & & \\
\hline Hearing tests & & & & \\
\hline $\begin{array}{l}\text { Recording stories on } \\
\text { tape }\end{array}$ & 8.00 & & & \\
\hline Total hours & 99.50 & 85.75 & 35.75 & 22.75 \\
\hline
\end{tabular}


increased tax base or special levy, the school district must have voter approval. Until 1967, the Board was consistently backed by the voter. However, in that year a request for a special operating levy was rejected by the voters on two separate occasions. Rather than put the measure to the electorate a third time, the Board decided to cut back on the budget and eliminated a number of services. On May 28, 1968 the School Board again went to the people, this time requesting a $\$ 9.875$ million increase in the tax base. ${ }^{64}$ A well-planned, privately financed promotional effort was a major factor in this campaign's success. Though the measure passed, it was apparent that the public would be more resistant to further tax increases.

In March,1970, the Portland School Board adopted a plan to revitalize the schools in the seventies. An integral part of this plan was the modernization of Portland's obsolete physical plant. ${ }^{65}$ This ambitious plan demanded a substantial expenditure of money at a time when the tax payer was tightening his belt. To gain the necessary support for the future, the School Board realized it was essential to bring the people closer to the schools. A major step in this direction

64 "Special Election Vote Analysis," a report by the Public Information Department, Portland Public Schools, Portland, Oregon: 28 January 1975, p. 61. (Mimeographed.)

65"Resolution \#3553," Board of Education, Portland Public Schools, (Portland, Oregon: 23 March 1970), p. 1. (Mimeographed.) 
was the recent decentralization of the school district and the establishment of citizen advisory boards for each subdistrict or area.

This concern for bringing the public closer to the schools was also a primary factor in the Board's decision to sponsor a school volunteer program. One of the purposes of the program as set forth in the School Board adopted proposal was to "provide a vehicle for the involvement of interested citizens in the work of the schools, thus improving community relations and support for school programs. "66

Similar goals are part of all school volunteer programs in the nation, and positive results have already been measured in some school districts. In urban areas, where a wall of isolation more often surrounds the school, efforts to recruit inner.city parents as school volunteers has proved a valuable bridge linking school and community. As outlined by William Stradley in an article in Grade Teacher, a more accurately informed public is a benefit of a school volunteer program. He further states that the school volunteer, through his presence in the school, is able to better understand the goals and objectives of the school program. The volunteer views both the strong and weak points of the schools. He sees the school's program and role "in terms of other people's experiences, interests, and values" as well as his own. ${ }^{66}$ Portland Cooperative Volunteer Aide Program, p. 1. 
He is better able to view the interrelated roles of school and family. 67 If this is true, it would then follow that volunteers are in a unique position to become active advocates of education programs.

\section{Local Testing of Assumption \#4}

A questionnaire was developed to test the validity of the Assumption \#4 hypothesis that "citizen participation and involvement, as provided in a School Volunteer Program, can help to improve relations between school and community." This questionnaire was administered on a pre-post basis to the approximately one hundred seventy VIPS who comprised the total population of VIPS working in the Cleveland High School district. The specific purpose of the survey was to determine the volunteer's degree of support for the Portland Schools and for the act of volunteering and to discover if there had been a change in level of support between pre- and post tests.

It should perhaps be conceded at the onset that more scientific designs could have been chosen to test the validity of the assumption. For example, in surveying volunteers regarding their perceptions of the act of volunteering and their attitudes toward the school district it would have been useful to have data from a control sample of persons

\section{7 William E. Stradley, "Who Was That Stranger I Saw in Your} Classroom?" Grade Teacher, September 1967, p. 89. 
not involved in the program. However, this option was not available due to a reluctance on the part of school district personnel to survey such persons.

Additionally, because the design limited itself to surveying only volunteers, the larger question of broad community support cannot be answered objectively.

As previously stated, the design for testing Assumption \#4 was based on a questionnaire administered as a pre- and post test. 68 The pre-test $w$ ith a letter of explanation was mailed to volunteers January 3, 1970; the post test was mailed July 2, 1970. Stamped selfaddressed envelopes were provided for return of the survey.

The questionnaire listed ten statements about the Portland Schools, volunteering, and education. 69 The respondent was asked to indicate attitude toward each statement in terms of total agreement, partial

68 Pre- in this case refers to the first time the questionnaire was administered and post refers to the second time the identical questionnaire was given. The timing of the pre-test suggests in no way that all volunteers being examined began their volunteering after January 3 . Rather it is used as an initial assessment against which attitudinal change over a specific time may be measured.

${ }^{69}$ This questionnaire may be found in Appendix $B$. 
agreement, lack of opinion, partial disagreement, or total disagreement. Statements 1, 2, 3 and 10 were designed to show support of the Portland Schools. Statements 5,7 and 9 were designed to indicate support for the use of volunteers in the schools. Statements 4,6 and 8 spoke to specific roles of the schools and to the role of the citizen in determining school policy. These latter statements were not designed to be scored.

Responses were tabulated and scored on a scale of 0 to 5 . Five points were recorded for a response of "totally agree" with the point score descending to one point for "totally disagree," and to zero for no response. Tabulation of point total and average score was made for statements, 1, 2, 3 and 10 and for statements 5,7 and 9 on each returned questionnaire. These responses were recorded on graphs (Figures 3,4 , 5 and 6 on pages 59 to 62) to determine if there was any correlation between level of support and length of volunteer activity.

One hundred twenty responses $(67.2 \%)$ were received from a total of one hundred seventy-four questionnaires mailed in January. Eighty-six responses from a total of one hundred sixty five (52.1\%) were recelved in July. Responses $1,2,3$ and 10 had an average score of 3.66 in the January tabulation. In July the average of responses to the same statements were scored at 3.73. Responses to statements 5 , 7 and 9 had an average score of 4.36 in January. In July the average of responses to the same statements was scored at 4.43 . 
Since the respondents in the first questionnaire were not in all instances the same persons responding to the second questionnaire, a further breakdown is necessary for more valid conclusions. Seventy-one volunteers answered both pre- and post tests and their responses were recorded by Figures 3, 4, 5 and 6, pages 59 to 62 . The average scores for this subgroup's responses for questions $1,2,3$ and 10 were 3.62 for the pretest and 3.84 for the post test. The increase of .22 from pre- to post test for this subgroup is greater than the .07 increase shown by the total group and would appear to support the supposition that the act of volunteering in the schools tends to make people more responsive to school needs.

The average scores of subgroup response to questions 5,7 and 9 for the first questionnaire was 4.59 pretest and 4.75 post test. Again the increase for the subgroup was greater than that for the total group: .16 as compared to .07 .

From these figures it would appear that volunteer service, with its consequent opportunity to gain an understanding of school problems, may be associated with support for school needs. This local finding tends to corroborate evidence found elsewhere in the nation. 


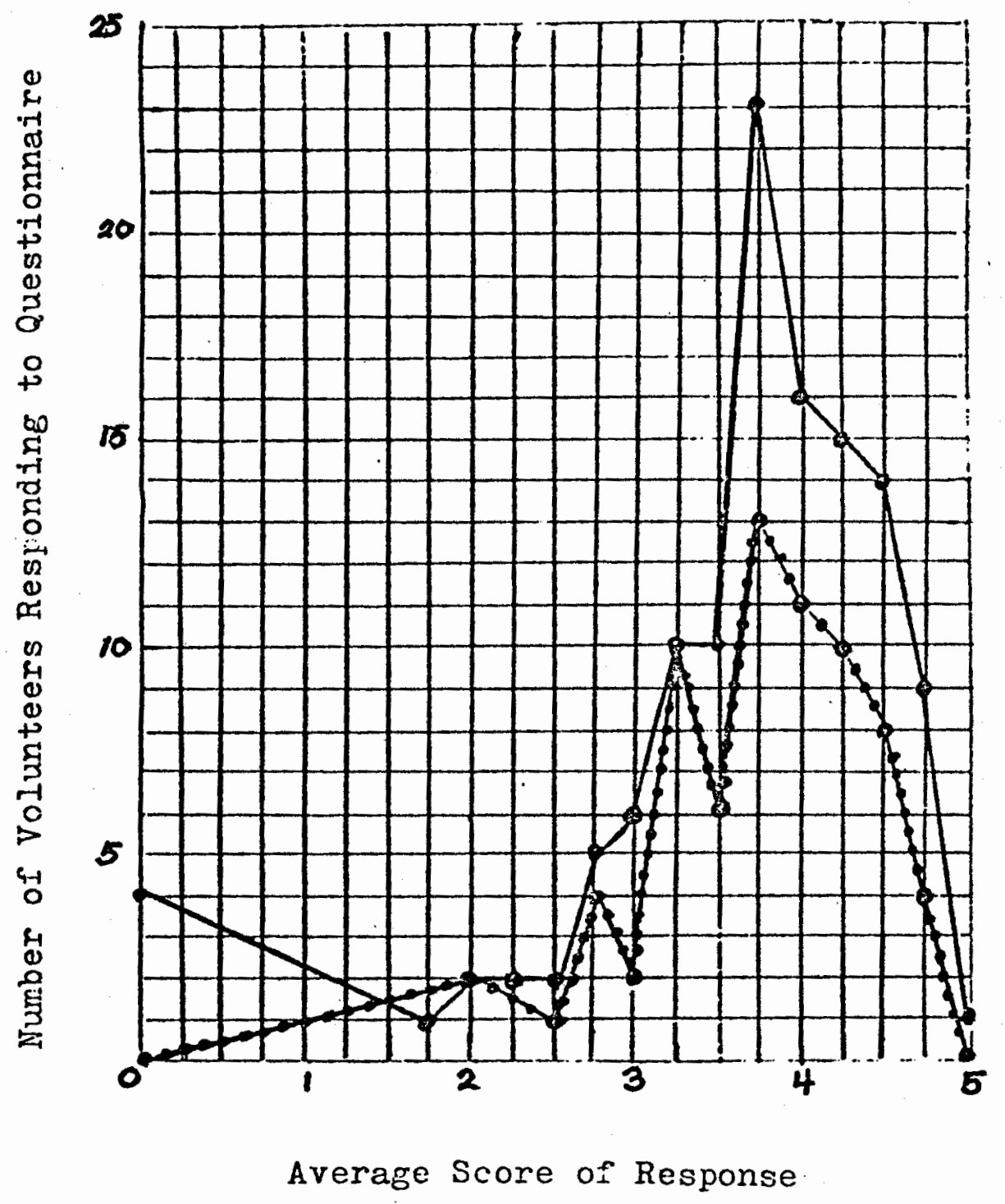

Figure 3. Level of support for the Portland Public Schools are shown by responses to Statements $1,2,3$, and 10 of a questionnaire given to Volunteers in Portland Schools, January 1970. Responses are scored on a scale of 0 to 5 with the highest number showing the greatest degree of support for a given statement. The solid black line represents responses from the subgroup answering both January and July questionnaires. 


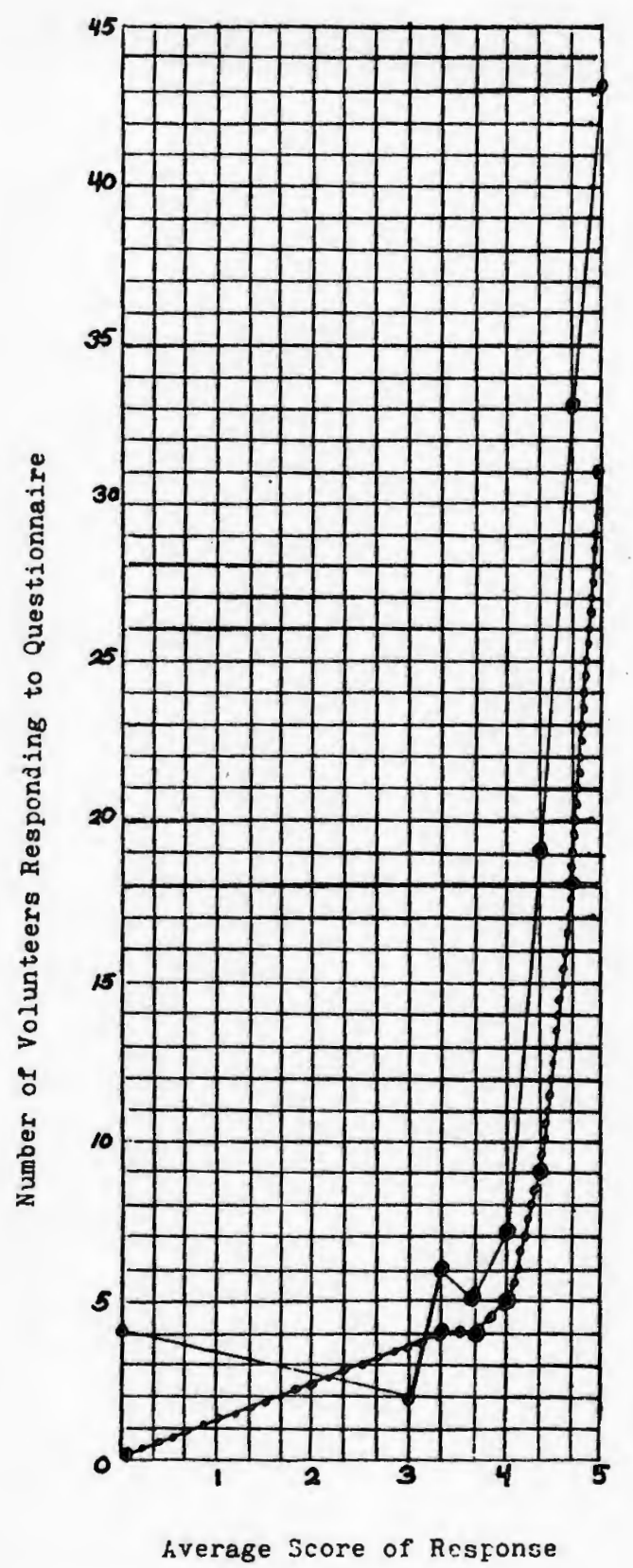

Figure 5. Level of support for the act of volunteering in schools as shown by responses to Statements 5,7 , and 9 of a questionnaire given to Volunteers in Portland Schools, January 1970.

Responses are scored on a scale of 0 to 5 with the higher number showing the greatest degree of support for a given statement. The solid black line represents total responses to the questionnaire. The dotted black line represents responses from the subgroup answering both January and July questionnaires. 


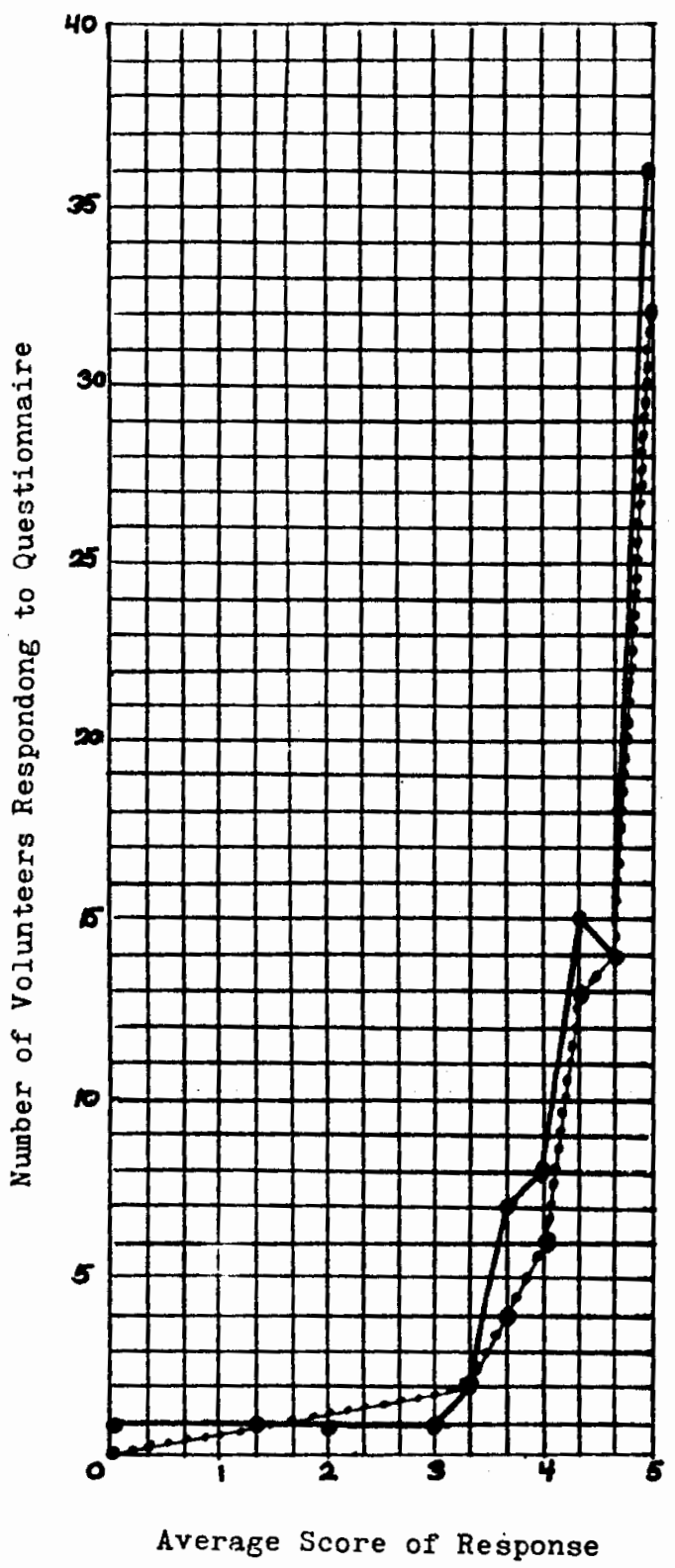

Figure 6. Level of support for the act of volunteering in schools as shown by responses to Statements 5,7 , and 9 of a questionnaire given to Volunteers in Portland Schools, July 1970. Responses are scored on a scale of 0 to 5 with the higher number showing the greatest degree of support for a given statement. The solid black line represents total responses to the questionnaire. The dotted black line respresents responses from a subgroup answering both January and July questionnaires. 


\section{CHAPTER VI}

\section{CONCLUSIONS AND RECOMMENDATIONS}

The conclusions and recommendations presented in this chapter were determined after a year and a half examination of the VIPS program in the Cleveland High School District. They are based on recorded Information, evaluative data, and the author's experiences and observations. As the initiator of the VIPS concept, the coordinator of the pilot project and later of the Cleveland area program for a year, a classroom volunteer, and a teacher assisted by volunteers, the author has drawn upon inferences and impressions felt while working with people in all facets of the VIPS program. These conclusions are subjective in nature and may not be fully defended in the data reported.

In this chapter discussion will first center on program needs which may be met by the central VIPS office and then expand to needs which may be met at the local school level.

\section{CHANGING ROLE OF THE VIPS DIRECTOR}

At the present time the central coordinator or director has focused her efforts on two fronts: 1 . the public relations functions of "telling the VIPS story" to numerous schools, P.T.A.s, service organizations, and interested persons, and 2. the assistance required by Individual schools to set up their volunteer programs. As the program 
expands and areas of responsibility are determined along the pattern set by the Cleveland High School district, the director should be able to delegate some of her present functions. In so doing, she will be able to shift her attention to the following growing needs of the program as it exists district-wide.

Orientation, Pre-service, and Inservice Programs

As the number of volunteers grows, there will be a definite need for development of workshops to prepare these volunteers for their assignments. An important thrust of the Director's job will be in this direction. Major volunteer programs across the country have training sessions as an integral part of their total program. This point is emphasized by Benjamin J. Henley, Director of the Washington, D. C., School Volunteer Program. Among guidelines that he sets forth for a successful volunteer program are: 1. "Use your volunteers to support and strengthen the all important teacher-pupil relationship and train your volunteers so that they understand their role"; and 2. "Use volunteers through the instructional program . . by providing training by the appropriate department in the school or school system." 70

One of many training programs is the example found in a fall 1966 letter to San Francisco School volunteers announcing a pilot work-

70 Bryce Perkins, Getting Better Results from Substitutes, Teacher Aides, and Volunteers, Successful School Management Series (Englewood Cliffs, New Jersey: Prentice Hall, Inc., 1966), p. 63. 
shop for the entire volunteer corps with the workshop composed of two parts: a general discussion of problems of "communicating, verbalizing, and listening" followed by smaller meetings to give specific working aids and suggestions to volunteers with similar areas of service. 71

In Portland the need for training was seen in the early stages of the VIPS program when it was discovered that a significant number of volunteers lacked self-confidence in their assignments. Others were reluctant to volunteer, thinking they did not have the background, skills, or talents they believed were a prerequisite to helping in the schools. With pre-service training most volunteers could overcome much of this feeling of inadequacy.

Orientation, pre-service and inservice workshops should assist the volunteer in developing a philosophy about the role of a volunteer in the school and an understanding of the importance of professional ethics. Demonstration of the type of work to be done with individuals, small groups, and classes as well as discussion of techniques, instructional methods, and materials to be used, should more adequately prepare a volunteer for assignment.

${ }^{71}$ Letter to Volunteers from the San Francisco Educational Auxiliary (San Francisco: SFEA, 30 September 1966), p. I. (Mimeographed.) Catholic School Journal 63 (January 1963): 35. 


\section{Internal Public Relations}

A volunteer needs to think of self as a capable person contributing not only to a local school's program, but also to a program of a larger, unified scope. It is important for a volunteer to have a feeling of belonging and sharing in a common enterprise. It should be recognized that there is also a need to treat volunteers more carefully than paraprofessionals since their only motivation to serve comes from within. ${ }^{73}$ Wallets are not involved in the transaction. For this reason a sincere effort to show appreciation to volunteers must be an integral part of the volunteer program. The volunteer's need for satisfaction may be partially met at the local level through good personal relations. At the central, more distant level this need may be partially met by establishing opportunities for exchange of ideas and by publication of a newsletter designed to give insight into the program as a whole and into the important role of the individual volunteer.

\section{$\underline{\text { Resource Search }}$}

Classroom enrichment is a key ingredient of the VIPS program. A community resource service to handle requests for presentations, while a continuous recruitment challenge, is extremely valuable to the schools. In Berkeley, Callfornia the resource service has become one of the busiest portions of the school volunteer program and of vital 
importance to the school system. ${ }^{74}$ Here in Portland efforts to recruit and coordinate resource personnel are in their infancy. They need to be stepped up and expanded.

\section{REQUIREMENTS AT THE LOCAL LEVEL}

Program Support from Principals and Staff

Comments from teachers using the VIPS program indicate they are generally pleased with the aid that they have received from volunteers. ${ }^{75}$ Unfortunately there have been more people who have volunteered than there have been job requests from teachers, pointing to a hesitancy by teachers to realize VIPS' potential. As stated in the pamphlet, Reaching the Neighborhood Parent, pubiished by the National School Volunteer Program, this hesitancy may be due to teachers regarding school volunteers with suspicion as a threat to professional status. To some teachers, a volunteer's presence in the schools may seem just one more item added to the heavy burden of school routine.

Resistance caused by such attitudes can best be broken down

74 "The SRV Story," SRVista, the newsletter of the School Resource Volunteers, Berkeley, California (April 1968), p. 4. (Mimeographed.)

75 "Volunteers in Portland Schools Progress Report," p. 7. 76 Wolf and Tunick, Reaching the Neighborhood Parent, p. 11. 
by encouragement from within the profession. Teachers who have had successful experience with a volunteer are probably the best salesmen for the program and should be encouraged to act in this capacity. At the same time the teaching profession must cooperate with the volunteer organization to make teachers aware of various areas of volunteer service and of specific uses of volunteers in the schools. The principal remains a key figure in the success of the volunteer program. For this reason, every effort should be made to develop strong support at this level of school administration. As an example, in San Francisco, mini-

workshops for principals were planned with this goal in mind. ${ }^{77} \mathrm{~A}$ similar venture could and should be made in Portland.

\section{Capable Personnel in Coordinator Positions}

An equally key figure in the success of the volunteer program is the coordinator at the local school. This individual must be committed to the program and willing to give the time necessary for the job. The Cleveland pilot project area produced ample evidence that the success of an individual school program was definitely dependent on the ability of that school's coordinator as she works directly with volunteers in recruitment and placement.

Placement in itself is a fairly straightforward process of determining "work needs to be done, evaluating available workers, and relating 
the workers to the work as satisfactorily as possible. "78 The success of placement requires additional skill and is dependent on good personal relationships. As stated by Harriet Naylor in a discussion of the use of volunteers today, "techniques and practices by themselves will not make a good placement plan; with them must be combined the understanding, the warm responsiveness, and the thoughtfulness that are vital to good human relations. " 79 These qualities along with organizational skills and an understanding of the school's community are required of the school coordinator, a position which may be difficult to fill.

In the VIPS program, selection of the local school coordinator is made jointly by school principal and P. T.A. president. They, therefore, are ultimately responsible for success in the volunteer program. Their positive commitment to the program goals is the first of many factors contributing to program success.

\section{SUMMARY}

The observations discussed in this chapter suggest a changing role for Portland's VIPS director. As the program expands, the director's function as a facilitator for the establishment of individual school VIPS

${ }^{78}$ Harriet H. Naylor, Volunteers Today--Finding, Training, and Working with Them (New York: Association Press, YMCA, 1967), p. 93 .

${ }^{79}$ Ibid. 
programs should diminish. As this occurs, it is recommended that the director focus her efforts on developing orientation and training sessions, on instituting a stepped-up resource search, and on encouraging positive internal relations within the VIPS program.

It is also recommended that principal and teacher support for the VIPS program be strengthened. To achieve this goal, the director should work cooperatively with school district personnel in a sensitive manner so that principals and teachers will not feel that the program is being imposed on them, but rather that a volunteer program should be adopted because it will help them to do a better job with students.

It is further recommended that the selection of school coordinators by P.T.A. and school personnel be made in a thoughtful manner recognizing the particular qualities required of that position. The coordinator, having much direct contact with school volunteers, is a key figure in helping them find satisfaction in an assignment. For this reason it is essential that the coordinator be well chosen.

The value of volunteers in schools is well documented by programs across the nation. In its initial efforts Portland appears to have set a firm foundation for a strong program. 
CHAPTER VII

POSTSCRIPT: THE PROGRAM AFTER SEVEN YEARS

School volunteerism has shown steady growth both locally in Portland and nationally in other cities across the country.

\section{THE NATIONAL SCENE}

Growth on the national scene is perhaps best illustrated by the growth of the National School Volunteer Program, Inc. As stated earlier in this paper, the NSVP, Inc. was organized in April 1964 wi th Ford Foundation funds to help local citizen groups and Boards of Education in the twenty largest cities, exclusive of New York, to establish their School Volunteer Programs or extend and strengthen existing programs. By 1975, NSVP, Inc. had expanded to include seven hundred affiliates. Though the Los Angeles program was the largest with fifteen thousand volunteers, school volunteer programs of two to three thousand were much more common. 81

During this period of growth the goals of NSVP, Inc. have remained intact. Its four basic functions are to:

${ }^{80}$ General Information Concerning NSVP, Inc., p. A-2. 81 Audrey Jackson, "Volunteer Way: NSVP, "American Education, April 1975, p. 12. 
1. provide national services toward helping local programs and school systems achleve standards of quality and effectiveness.

2. help local programs to expand efforts to meet increasing student needs.

3. insure that all school volunteer programs and activities emphasize the central role of citizen participation in the schools.

4. seek to strengthen school volunteer programs as community institutions capable of mobilizing resources and integrating services on behalf of students both as advocates and toward providing specific services.

In addition to assistance on an individual basis, NSVP, Inc.

conducts regional and national workshops on matters of general concern. The professional exchange fostered by such meetings is effective in generating insights and improvement for many school districts and local programs. 83

\section{THE LOCAL SCENE}

Volunteers in Portland Schools is an active affiliate of NSVP, Inc. VIPS director, Mrs. Freddie Herbert, also serves as Oregon chairman for NSVP, Inc. and in this dual role has developed a strong link to the national organization.

Since its establishment as a city-wide school volunteer program with a salaried director in June 1969, VIPS has shown steady growth. In

Ibid.

${ }^{83}$ Ibid. , p. 18 . 
an annual report, Volunteers in Portland Schools director, Freddie Herbert, listed the program's growth as follows:

$$
\begin{aligned}
& 1970 \text { - } 744 \text { volunteers } \\
& 1971 \text { - } 1250 \text { volunteers } \\
& 1972 \text { - } 1808 \text { volunteers } \\
& 1973 \text { - } 2076 \text { volunteers } \\
& 1974 \text { - } 2366 \text { volunteers } \\
& 1975 \text { - } 2855 \text { volunteers. }
\end{aligned}
$$

For the school year 1975-1976 the number of volunteers increased to 3288 with approximately $85 \%$ of Portland's schools served by volunteers. ${ }^{85}$

The impact of volunteers on the schools may be further illustrated by looking at statistics for donated hours of service. As an example, in 1974-1975 volunteers worked approximately 16,689 hours per month ${ }^{86}$ This figure represents thousands of dollars that otherwise might have been spent on salaries of educational personnel.

In the period, 1969-1976, the growth of the Portland program has followed a structure modified from that set forth in the School Board adopted proposal for a Portland Cooperative Aide Program. (See Figure 1, page 19.) As originally designed, the structure of VIPS was essentially that of a three tiered pyramid with the volunteer programs of all schools within a given geographical region reporting directly to a single section coordinator who in turn was responsible to the director of VIPS. This plan paralleled the structure of the local P.T.A. Council and was chosen

84 Freddie Herbert,"Report: Volunteers in Portland Schools 1974-1975" (Portland: 1975), p. 5. (Mimeographed.)

85 Interview with Mrs. Freddie Herbert, Director of VIPS, Portland, Oregon: 18 August 1976.

${ }^{86}$ Freddie Herbert, "Report: Volunteers in Portland Schools, " p.5. 
to allow for maximum P.T.A. support at the various levels.

As a fact of operation, however, the middle tier of this pyramid has not functioned(with the exception of the Cleveland High School area during the school year 1969-1970.) Mrs. Herbert believes that this situation was due in part to a resistance from individual schools to work together and, in part, to a failure of P.T.A. to lend support for organization at the section level. In the author's opinion it is unfortunate that this situation has developed. Section coordination had proved its value in the brief period of the Cleveland area project, 1969-1970. While at that time it was noted that schools were reluctant to be subject to central direction, they were willing to cooperate at a more local level. In the Cleveland area, neighboring schools had begun to work together to fill volunteer needs and school coordinators had developed a feeling of camaraderie with the sharing of ideas and concerns.

The chart below, Figure 7, lllustrates the program structure

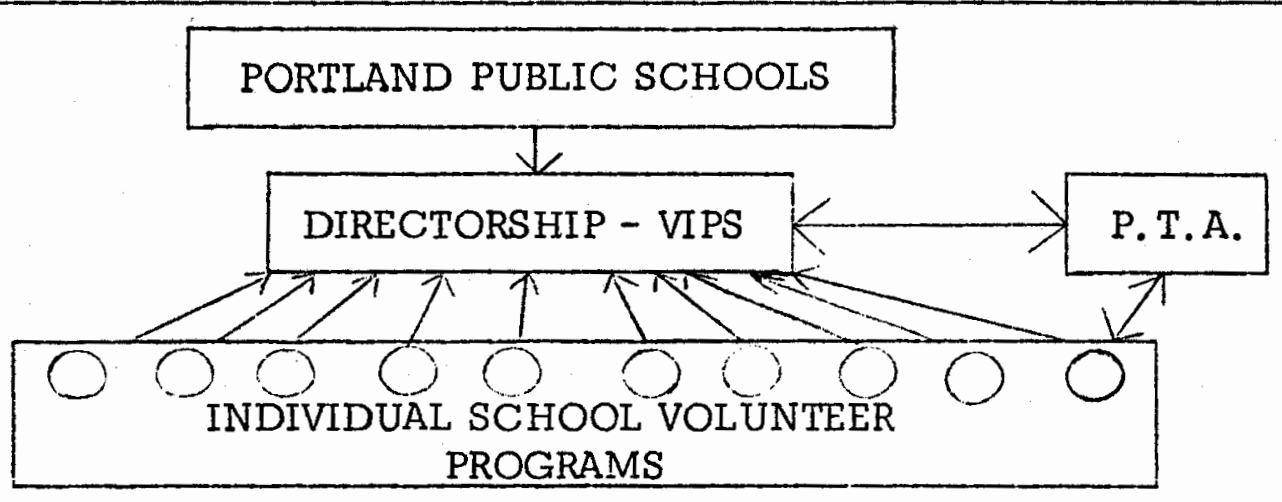

Figure 7. Volunteers in Portland Schools organizational structure, 1976. 
as it exists today and may be compared to Figure 1, page 19, which shows the program's structure as originally conceived.

While overall program structure has changed, the organization of the individual school VIPS program remains essentially the same and is shown in the diagram below, Figure 8 . In this chart the position of staff coordinator may assume some administrative responsibilities from the principal and is optional as indicated by the dotted lines. ${ }^{87}$

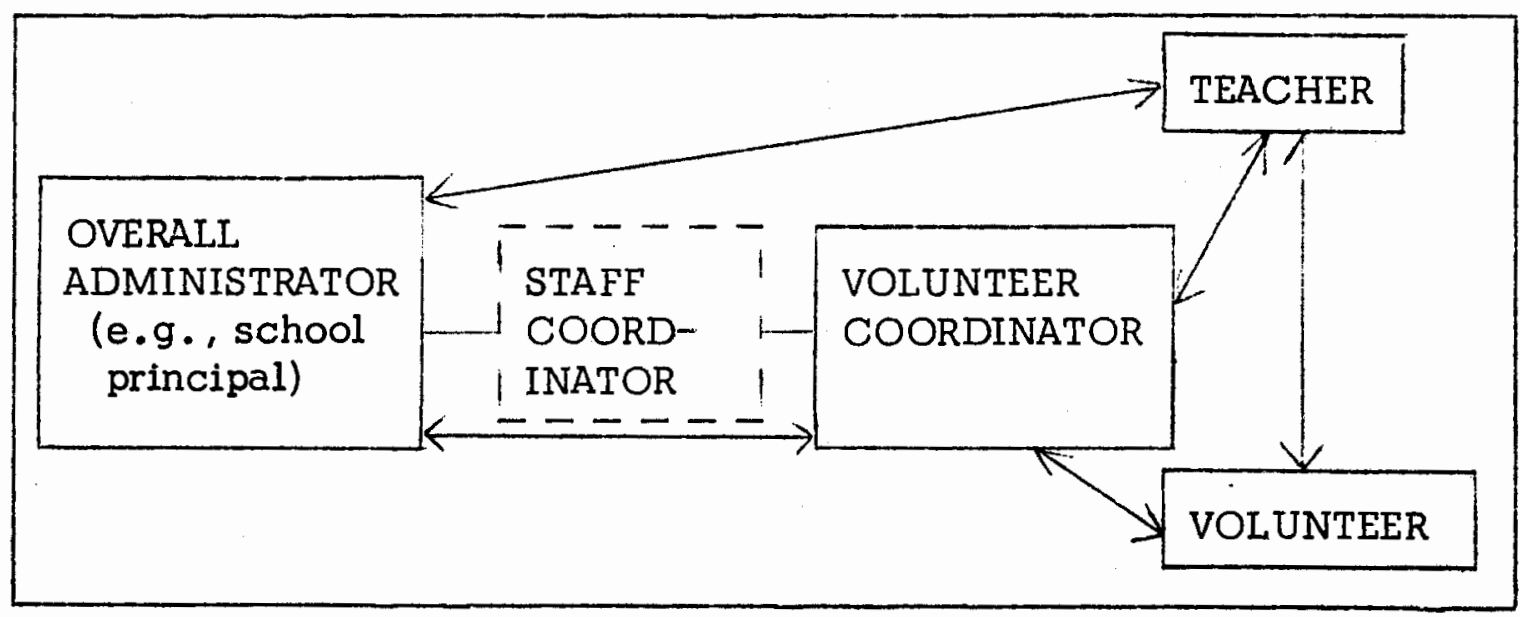

Figure 8. Organization of Volunteers in Portland Schools program in participating schools, 1976.

Aside from the organizational and structural changes noted, the philosophy of VIPS remains as originally set forth and the goals of the program are essentially the goals established by the school board in

\section{7} 1974), p. 6. (Mimeographed Handbook.) 
February 1969. ${ }^{88}$ Written material, such as volunteer questionnaires, teacher requests for classroom help, and information for volunteers, is virtually unchanged.

Since VIPS became a city-wide program, its director, Mrs. Herbert, has served to assist in any way needed. Her duties have included recruitment of volunteers, volunteer orientation and training, volunteer placement, trouble shooting when necessary, public relations including the editing of a quarterly newsletter, "Tie Line," and evaluation.

In her years as program director, Mrs. Herbert has developed a guide for pre-service orientation of volunteers and has worked particulary hard to gain principal support for the VIPS program. From her experience, Mrs. Herbert has observed that the success of an individual school volunteer program may be attributed to the interest and support given by that school's principal. For this reason,Mrs. Herbert has developed a clear outline of the principal's responsibilities to VIPS. In addition she has asked to meet with the principals of the three adminIstrative areas in the fall of 1976 to further "sell" the VIPS program. This step she believes is essential to the continuance of a strong program. 89

One of the greatest problems of the VIPS program as observed

${ }^{88}$ These goals are listed page 12 of this thesis. 89 Interview with Mrs. Freddie Herbert, Director of VIPS, Portland Oregon: 18 August 1976. 
by Mrs. Herbert is overcoming teacher resistance to using volunteers. As she notes, once teachers participate they are the program's biggest boosters. 90

Another problem she has observed is the resistance shown by individual schools to central direction. School coordinators, she believes, often become very possessive of their individual programs and are consequently reluctant to get together to share experiences. In an effort to overcome this, Mrs. Herbert has conducted fall workshops for coordinators. The attendance at these meetings has not been good and the feedback to volunteers has been uneven. 91

Resistance by individual schools to central direction and a hesitation by teachers to utilize volunteers, however, are not unique to Portland. They are a phenomena found in school volunteer programs across the nation. 92

In spite of these frustrations, Mrs. Herbert believes that VIPS has proved to be a very valuable program. Aside from a great assistance to teachers in terms of relief from certain tasks, VIPS has been of inestimable value to children and volunteers. For the volunteer it adds greater "meaning to life" by making a personal contribution to

90 Freddie Herbert, VIPS, People Who Care about Kids, p. 1. 91 Interview with Mrs. Freddie Herbert, 18 August 1976. 92 Ibid. 
others. For the child it may mean a positive change in direction. Mrs. Herbert believes that a volunteer's "taking time now to work with a child, to listen and to show love to that child may mean a savings of thousands of dollars in the future." 93

Across the nation many testimonials have been given to school volunteers. They are perhaps best capsulated in this simple statement: Everyone associated with a school volunteer program is a winner--the volunteers, the student, and the community.

Ibid.

94 Audrey Jackson, "Volunteer Way: NSVP،" p. 18. 


\section{LIST OF WORKS CONSULTED}

Administrative Leadership Service. Administrative Leadership: Teacher Aides or Auxiliary Personnel. Arlington, Va.: Educational Service Bureau, Inc., 1966.

Bahr, Jerome. "Non-Professional Teachers Enliven the Subject Matter." Clearing House 43 (April 1969): 494-496.

Blanchard, Robert W. "Portland Schools for the Seventies." Statement at a special meeting of the Portland School Board, Portland, 21 January 1970. (Mimeographed.)

Boudreau, Sister Phyllis. "Teacher Aides." National Catholic Educational Association Bulletin (August 1967): p. 148-152.

Boyles, Beatrice C. "New Branches Grow on the Educational Family Tree." National Elementary Principal, May 1967, pp. 38-39.

Burkhardt, Ann Strayer. "The Trained Volunteer and the Elementary Library." American School Board Journal 150 (March 1965): $15-16$.

Carlson, Julie. "If You're On Your Own . . When to Find Resource People and How to Use Them." Grade Teacher, September 1967, p. 92 .

Chandler, B. J.; Stiles, Lindley J.; and Kitsuse, John I., eds. Education in Urban Society. New York City: Dodd, Mead and Co., 1962 .

Conant, James B. Slums and Suburbs. New York City: McGraw-Hill Book Co., Inc., 1961 .

Cruickshank, William M. and Haring, Norris G. A Demonstration: Assistance for Teachers of Exceptional Children. Syracuse: Syracuse University Press, 1957.

Cunningham, Mary W. "A Corrected Reading Program Using Volunteer Help." Catholic School Journal 67 (March 1967): 70-71.

Eddy, Elizabeth M. Walk the White Line. Garden City, N. Y.: Anchor Books, Doubleday \& Co., Inc., 1967. 
"Elementary School Enrollment Report as of September 26, 1969."

(Portland, Oregon: Administrative Research Department, Portland Public Schools, January 1970). (Mimeographed.)

Ferber, Edna. "Miss Braids and the Growler." American Education, November 1968, pp. 10-12.

Fleming, Thomas J. "Let Me Help You Learn." Redbook, October, 1967, pp. $46+$.

Foster, Robert E. "In Slow Gear--Volunteer Teacher Aides." The Instructor, September 1964, pp. 136-137.

Freund, Janet. "Time and Knowledge to Share." The Elementary School Journal 65 (April 1965): 351-358.

Goul, J. "Boise Likes Its School Volunteers." Today's Education, Nov.-Dec. 1975, pp. 72-73.

Genevieve Arcement, Sister. "A Teacher Aide Program That Really

Works." Catholic School Journal 67 (December 1969): 26-27.

"Helping Hands." The Times Educational Supplement, January 21, 1966, pp. $154-155$.

Herbert, Freddie. Director, Volunteers in Portland Schools, Portland, Oregon. Interview, 18 August 1976.

- Report: Volunteers in Portland Schools 1974-1975." Portland: 1975. (Mimeographed.)

- NIPS, People Who Care about Kids." Portland: 1974. (Mimeographed Handbook.)

Hillenbrand, Robert F. "An Elementary Principal Views the Feminine Mystique." National Elementary Principal, May 1976, pp. 53-55.

Hunter, Madeline. "Staff Meeting." Instructor, May 1974, pp. 20-21. Iacolucci, Grace M. "Parents as Teachers Aides." Childhood Education 44 (March 1968): 424-427.

Jackson, Audrey. "Volunteer Way: NSVP." American Education, 
April 1975, pp. 11-18.

Janowitz, Gayle. Helping Hands: Volunteer Work in Education. Chicago: University of Chicago Press, 1965.

Jensen, Pauline L. "In Minneapolis: Hundreds of Volunteers Help Teachers Teach Better." Grade Teacher, September 1967, pp. 90-92.

Johnson, Guion Griffis. Volunteers in Community Service. Chapel Hill, N. C.: The North Carolina Council of Women's Organizations, Inc. , 1967 .

Jordan, William C. "How to Put Parents to Work in the Classroom." Nations Schools, February 1968, pp. 76-77.

Kenison, Carolyn, ed. Volunteer Views. New York: National School Volunteer Program, Inc. October 1969.

Kerber, August and Bommarito, Barbara, eds. The Schools and the Urban Crisis. New York: Holt, Rinehart and Winston, 1965.

Klebaner, Ruth Perlman. "School Volunteers: A New Challenge." National Elementary Principal, May 1967, pp. 13-16.

Letter to Volunteers from the San Francisco Education Auxiliary. San Francisco: SFEA, 30 September 1966 . (Mimeographed.)

M. Eugene, Sister. "A Volunteer Teacher Aide Program." Catholic School Journal 63 (January 1963): 34-36.

Miller, James Nathan. "Robert Finds a Friend." The PTA Magazine, June 1966, pp. 4-7.

National Commission on Teacher Education and Professional Standards. Auxiliary School Personnel. National Education Assn. , Washington, D. C., 1967.

Naylor, Harriet $H$. Volunteers Today--Finding, Training, and Working with Them. New York: Association Press, YMCA, 1967.

Newton, Eunice Shaed. "Training the Volunteer Reading Tutor." Journal of Reading 8 (January 1965): 169-174.

Nielsen, Wilhelmine R. "Parents Enrich Classroom Program." Child- 
hood Education 44 (March 1968): 416-419.

"Non Professionals Tutor Disadvantaged." Volunteer Views. New York: National School Volunteer Program, Inc., October 1969.

Norton, Eloise. "School Libraries and Volunteer Help." Peabody Journal of Education 43 (July 1965): 18-20.

Norville, Mary B. "Volunteers in Portland Schools (VI PS), Cleveland Area Pilot Project, " Portland, 12 June 1969. (Typewritten.)

NSVP, Inc. "General Information Concerning NSVP, Inc." New York: 1968. (Mimeographed.)

Payne, William H. "Organized Tutoring: New Dimensions for Increasing Skills." Journal of Secondary Education 42 (January 1967): 21-24.

Perkins, Bryce. Getting Better Results from Substitutes, Teachers Aides, and Volunteers. Success ful School Management Series. Englewood Cliffs, N. J.: Prentice-Hall, Inc., 1966.

Phyliss Bourdeau, Sister. "Teacher Aides." National Catholic Educational Association Bulletin, August 1967, pp. 148-152.

"Portland Cooperative Volunteer Aide Program." A proposal presented to the Portland School Board, Portland, 10 February 1969. (Mimeographed.)

Portland Public Schools. "Volunteers in Portland Schools, Progress Report." June 19, 1969. (Mimeographed.)

Portland Public Schools, Board of Directors, Portland, Oregon. Discussion at the Board meeting, 10 February 1969.

Portland Public Schools, Board of Directors, Portland, Oregon. Discussion at the Board meeting, 23 June 1969.

"Portland Teachers Look at Discipline." A report of the Portland Association of Teachers, Teacher Education and Professional Standards Committee. Portland, Oregon, September 1969. (Mimeographed.)

"Profile." Volunteers in Education. Washington, D. C.: Office of Citizen Participation, U. S. Office of Education, December 1969. 
Rainwater, Lloyd. Principal, Duniway School. Portland, Oregon. Interview, 7 March 1970.

Reed. Betty Jan. "Thank You for Coming!" The Instructor, October 1967, pp. 77-78.

Richardson, Joe A. and Burgoon, Janet. "A Volunteer Talent Pool and the Public School." Educational Leadership 26 (April 1969): 703 and 709.

"Resolution \#3553." Board of Education, Portland Public Schools. Portland, Oregon: 23 March 1970. (Mimeographed.)

Schindler-Rainman, Dr. Eva. "The New Day of the Volunteer." Transcript from a speech delivered at a Workshop on Volunteers sponsored by the Junior League of Portland, Portland, Oregon, 13 October 1969. (Mimeographed.)

School Volunteer Program, Office of Urban Affairs. "Procedure Book for Officers and Chairman of the Executive Board." Los Angeles: Los Angeles City Schools, July 1968. (Mimeographed.)

Scientific American. Cities. New York; Alfred A. Knopf, Inc., 1967.

Shaw, Jack; Otte, Roy W.; and Keister, Margaret M. "Helping Parents Understand the School Program." The Instructor, June 1969, p. 17.

Sheldon, Eleanor Bernert; Hudson, James R.; and Glazier, Raymond A. "Administrative Implications of Integration Plans for Schools: Open Enrollment in New York City." In Schools in a Changing Society, ed. by Albert J. Reiss Jr. New York: The Free Press, 1965 .

Shipp, Mary D. "Teacher Aides: A Survey." The National Elementary Principal, May 1967, pp. 30-33.

Sleisenger, Lenore. Guidebook for the Volunteer Reading Teacher. New York: Teachers College Press, Columbia University, 1965.

"Special Election Vote Analysis." A report by the Public Information Department, Portland Public Schools. Portland, Oregon: 28 January 1975. (Mimeographed.)

Stone, Virginia. "Interest Stimulators." The Instructor, March 1968, p.99. 
Stradley, William E. "Who Was That Stranger I Saw in Your Classroom?" Grade Teacher, September 1967, pp. 88-89.

Stringfellow, William. Free in Obedience. New York: The Seabury Press, 1964.

Teacher Education and Professional Standards Committee. Portland Teachers Look at Discipline. Portland: Portland Association of Teachers, September 1969.

"The SRV Story." SRVista, Newsletter of the School Resource Volunteers, Berkeley, California, April 1968. (Mimeographed.)

"They Can't Say No." American Education, May 1969, p. 28.

Turney, David T. Secretaries for Teachers. Nashville, Tenn: Department of Education, George Peabody College for Teachers, 1962.

U. S. Department of Health, Education and Welfare. Staffing for Better Schools, by Malcolm Provus, et al. Washington, D. C.: Government Printing Office, 1967.

"View II--Volunteers in Education Workshops II," Workshop proceedings at the College of San Mateo, San Mateo, California, 20 April 1968. (Mimeographed.)

"Volunteers in Portland Schools Progress Report." Portland: Portland Public Schools, 19 June 1969. (Mimeographed.)

Washington School of Psychiatry. TAP: The Teacher Aide Program; A Role Sensitivity Approach to Training Aides for Classroom Work with Children in Elementary School. Washington, D. C.: Model School Division of the Public Schools of the District of Columbia, 1967.

Weed, Florence C. "It Worked for Me." Grade Teacher, March 1969, p. 30 .

Witt, Rose Marie. "Mothers Volunteer as Teachers' Aides." Catholic School Journal 59 (September 1959): 68-69.

Wolf, Anna W. M. and Tunick, Adele B. Reaching the Neighborhood Parent. New York: National School Volunteer Program of the Public Education Association, 1966. 
Wolf, Elinor. "Reveille for Volunteers." American Education, November 1968 , pp. 26-28.

Wolf, Elinor K. A letter to volunteers in Volunteers in Education. Washington, D. C.: Office of Citizen Participation, U. S. Office of Education, December 1969.

Wolman, Thelma G. and Shelley, Florence D. "Volunteers in the Public School: Bonus or Burden?" National Elementary Principal, May 1967, pp. 34-37.

Zook, Nancy Gibbons. "Menu: A Treat for Teachers." National Parent Teacher, June 1960, pp. 29-31. 


\section{APPENDIX A}

FORMS DEVELOPED FOR THE OPERATION OF THE VIPS PILOT PROJECT, 1969

PAGE

Personal Interview Form...................... 87

Questionnaire on Community Resources............. 88

Resource Request Form....................... 89

Request for Volunteer Help in the Classroom.......... 90

Information for Volunteers ..................... 91

Information for Teachers..................... 92

Information for Coordinators.................. 94 
VOLONTEERS IN FORTIAND SCHOOLS

PEKSONAL INTERVIEW FORM

Date

MR.

ivS.

iISS,

Last Name (Flease Print) Flrst Name

Name of Spouse

ZIP

HOME ADDRISS

CODE TFIEPHONE

WORK OR VOLUNTEER EXPERIENCE

SCHOOL PREFEFENCE FOR VOLUNTEER ASSIGMMNT: Locel High school - Any grade school within your high school section : Ans school in the district.

DAYS AND TIME AVAILABLE

GRADE LEVEL PREFERRE; Pre-K_ Kdgn.__Gr. 1-3_Gr. 4-6_G_Gr. 7-8_Gr. 9-12

TYPI OF WOFK FREFEFFED: Library__eneral Classroom_One-to-one__Reading

ArIthmetic__Science__English and Literature__ivalc__Arts and Crafts

Erane_Hiome Ec.___Shop__P.L._Clericel__Supervision__Lunch___For. Lang.__

Lab. help__ Counselling offlce__Social Work or Nhursing (some exp. required)

Other.

INSTRUWWT PLAYED

FOREIGN LANGUAGE SPOKEN

DO YOUR CHILDREN ATTEND THE POETLAND POBLIC SGHOOLS?

IF SO, LIST THE

SCHOOLS AID TEACHERS

\section{EHWRCENCY IHTCRMATION}

In case of emergency please notify: (Your doctor and one other peraon) Name Address Telephone

Interriowed by 
VOUNTEERS IN PORTLAND SCHOOLS

QUESTIONNAIRE ON COMIUNITY RESOURCES

NAME

Telephone :

Address :

1. What coliections do you have?

(Stamps, autographs, dolls, butterflies, records, etc.)

2. What special talents do you have?

(Singing, dancing, acting, playing a musical instrument, magic, etc.)

3. What hobbies do you have?

(Photcgraphy, woodcarving, leathercraft, nature study, gardening, etc.)

4. Do you have special knowledge of the customs, food, or culture of foreign countries?

(Please specify country)

5. Do you have movies or slides of foreign countries or places of interest in the United States?

$$
\text { (Please specify) }
$$

6. Would your occupation be of particular interest to children?

\section{(Please specify)}

7. Do you have a factory or other place of business that might be interesting for children to visit?

$$
\text { (Please specify) }
$$

8. Are you in government service? If so, what branch?

9. Do you have any other talents, skills, or interests not covered by this questionnaire?

(Please specify)

10. May we call on you occasionally to contribute your time and talent to enrich the education of children?

Days when you are available

Tine when you are available

By special arrangement

11. Do you have friends or neighbors who would be interested in similar service?

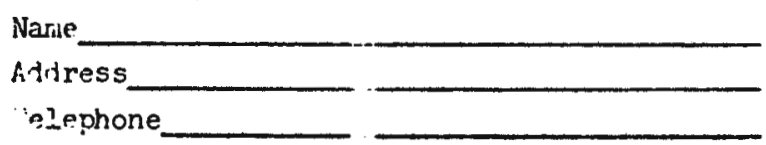


200 N. E. Beech

VOLUNTEERS IN PORTLAND SCHOOLS COMMUNITY RESOURCES SERVICE CONFIRMATION

Phone: 288-5361

Ext. 66

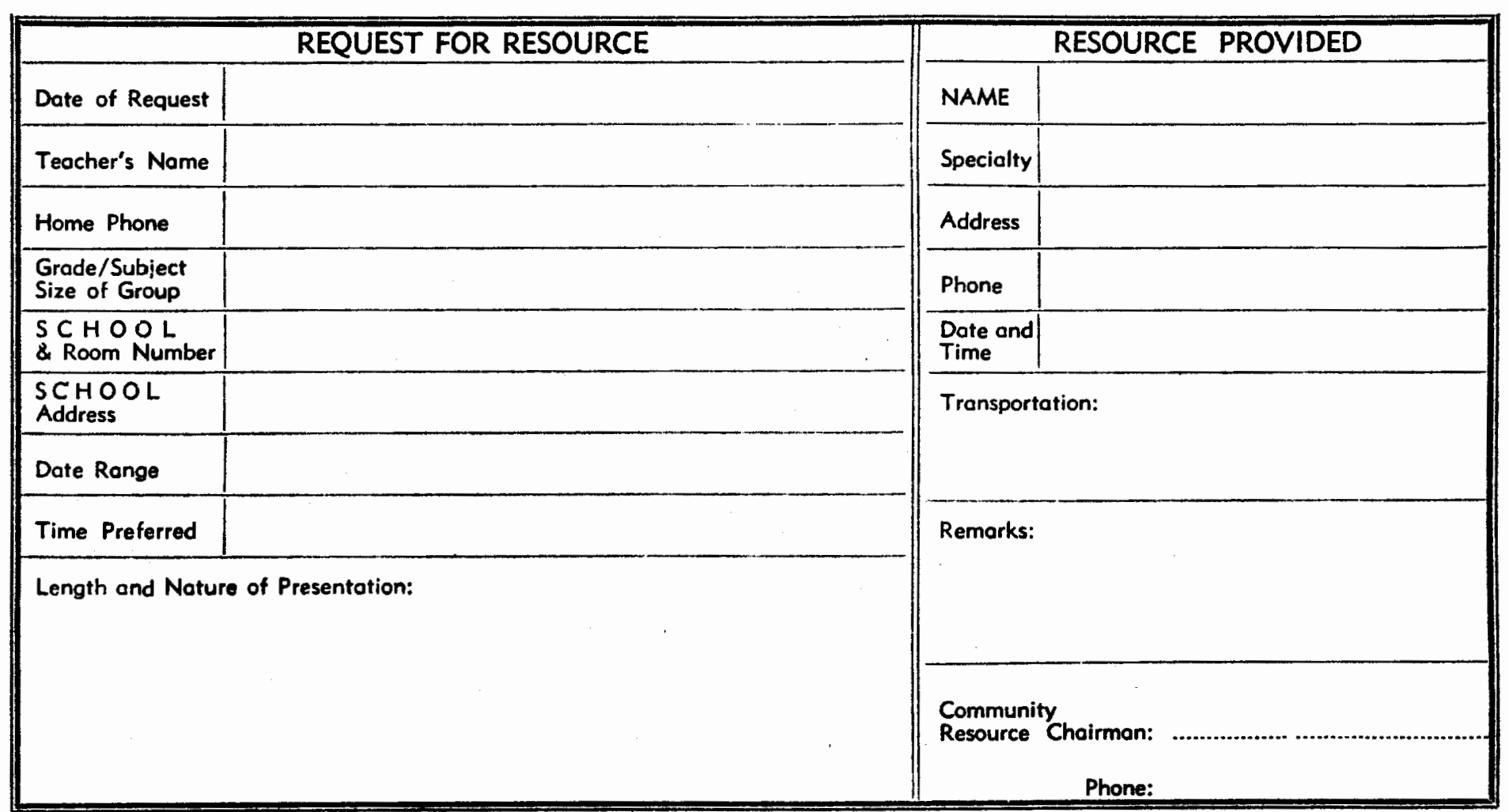




\section{REQUEST FOR VOLUNTEER HELP IN THE CLASSROOM}

Type of volunteer service desired

Grade

Subject

Number of students involved

If volunteer help is desired on a continuing basis, complete the schedule below.

\begin{tabular}{|c|c|c|c|c|c|}
\hline Days needed & $M$ & $T$ & W & TH & $\mathbf{F}$ \\
\hline Time needed & & & & & \\
\hline
\end{tabular}

Dates and times desired if not on a continuing basis

Additional comments

(special considerations, requirements, problems)

Teacher's name

School
Home phone

Date of request 


\section{YOLUNTWXRS IN PORTIAND SCHOOLS}

\section{INPORMATION FOR VOLUNTEERS:}

The Volunteers In Portland Schoolar Program is sponsored jointly by the Portland School Diatrict and the Portland Council, PTA. Its purpose is to extend the teacher's effectiveness by supplementing his work in the claseroom. Volunteers are therefore expected to do whatever is asked of them, Including some of the mechanical chores with which all teachers are burdened. The volunteer's cooperative attitude, expressed in the wilingness to provide any needed services cheerfully, is deeply valued.

To insure the success of a volunteer program, the volunteer should agree to the following basic assumptions :

1. Volunteers will not be used to replace teachers or regular paid aides. The teacher must retain ultinate responsibility for his own educational program. His judgment is at all times final.

2. Volunteers shall be used only by those persons who request such aervices. In no case will a volunteer be assigned to a teacher who does not indicate an interest in such services.

3. Teachers are the final judges of whether they can use a particular volunteer and are free at any tine to discontinue the use of helpers. If the situation warrants, the volunteer may ask for reassignment. Coordinators at oach school will make whatever adjustments are desired by either the teacher or volunteer.

4. A volunteer assignment requires a professional columtinent. It is a job. Dependability is essential. The teacher must be notified oufficlently in advance if the volunteer is unable to fulfill his obligation.

5. Professional ethics require that volunteers do not discuss teachers, pupils, or school affairs with other poople.

6. Volunteers must present a good example of appearance and behavior at all times.

7. Volunteers shall have an application on file prior to their performance of any service. Included shall be a TB card indicating negative results.

8. Volunteers shall participate in orientation sessions and when needed, spectallzed training sessions.

With volunteers cosimitted to the ides of genuine service, the Volunteers In Portland Schools' Program has great potential. It can increase the teacher's affectivenesi, provide enrichment opportunities in the school, and foster improved commity relations and support for school programs. 


\section{VOWNMEERS IN PORTLAïU SCHCOLS}

INFORI ATION FOR TEACHEFS:

What is V. I. P. S.?

The Volunteers In Fortland Schools' Prczram is sponsored jointly by the Fortland School District and the Fortland Council, PTA. Its pirpose is to exter.d the effectiveness of the teacher by supplezentine his work in the ciasiroom. The operation of the volunteer program is twc-fold. It provides volurteers for classroom assistance on a regular basis under the direct supervision of teachers. In adition, it provides classroom enrichment by bringing commity resource volunteers to the schnols to give special presentations and demonstrations.

Who may request volunteer help?

Any certified employee of the Portland Public Schools may request voiunteer assistance.

What are solue of the tilings that classrocm teachers :avy ask o vclun: eal to do':

Assist individuals or sniall groups by:

Practicing oral and written work; listening to children read and reading to them; drilling on number facts, spelling and handwriting; doine physical exercises; tutoring in subject areas, etc.

Assist generally in the classroon by:

Circulating to answer questions thile the children are duing seat-work; correcting spelling papers, work sheets, etc. and ㅅplaining corrections to students individually; providing vpecizl activities in skill area; assisting stlidents who are working or: special projects, accompanying a class on field trips, etc.

Assist the teacher:

Helping with housekeeping duties; preparing master carbons ar: other materials; doing visual aicis; preparing bulletin boards. making tapes; collecting pictures for a picture file; etc.

Most classroom volunteer 3 do a variety of the above. They are not exicsicd to handle disciplinary situations.

How much planning is necessary?

Teacher planning can pay large dividends in using volunteers effectivelj. The teacher should:

1. Decide specifically what the volunteer will do.

2. Schedule a pre-briefing session with the volunteer in orae: to:

a. determine special abilities of the volunteer.

b. as fully as possible inform the volunteer of his duties.

3. Prepare the class (or indiviuual sujaent) so that tine ch.ild.en vill know who the volunteer is and what she vill be doing.

4. Have plan and material ready when the veluntcer conc's.

5. Kaike sure the volunteer feels thet the tencher is avajlabis :answer questions and give guidance. 
What happens if the teacher is not satisfied with his volunteer help?

Inmediate evaluation follow-up will be conducted following an individual's first volunteer assignment. The school coordinator will, in most cases, be responsible for insuring that the teacher and/or the principal reports on the effectiveress of the individual. If a teacher is not satisfied with volunteer help, he should notify his coordinator or principal. The school coordinator has the responsibility to work out problems and reassign volunteers when necessary.

How does a teacher arrange for volunteer help?

The teacher may fill out a VIPS request form and leave it in the VIPS box in the school office. The more information given, the greater is the likellhood that the best volunteer will be found.

Whatever the teacher's need, the VIPS hopes to be of service.

VIPS Contact

Address

Phone 


\section{VOLUN TEERS IN PORTLAND SCHOOLE}

DFORUAA TION FOF: SCHOOL COOFD NATORS:

The school coordinator serves as a key person in the Volunteers in Portland schools' Program by providing a link between the school, the community, the volunteers and Volunteers in Portland Schcr's. Her civtles include the processing of requests for volunteer service and follow.-up evaluation of volunteer assistance. she also has the responsibility for the recruitment of volunteers from the school neighborhood in cooperation with the local PTA and other neighborhood agencies.

$\checkmark$ th every school different, the school coorcinator must be flexible and adapt her job to the school and its nelghborhood. She may undertake all obligations herself or she may delegate some of her duties (eg. recruitment) to others. She, however, maintains the responsibility for the volunteer program in her school.

The school coordinator must work closely with the section coordinator, looking to her for guidance and for placement of volunteers.

\section{Mechanics of Coordination:}

- Interpret aims, purposes and policiss of Volunteers in Portland Schools

1. To principal... Get acquainted; give him appropriate written materials if he doesr't already have them (policy, organization chart, etc.). Determine the person to relate administratively. There may be a teacher liaison in addition to the adri inistrative contact in each school.

Arrange for a VIPS box in the cffice.

2. To staff... Fee that they have all printed material relative to their role in the volunteer program. Eee that they have a clear understanding of the mechanics for making requests and for follow-up evaluation. Personal contact with the teachers is important in a success.ul program.

3. To the community.... In most cases the local P rA will serve 28 a liaison to the neighborhood. Se sure it is well-informed about the VIPS. In some areas community support may also be gained from other local organizations (eg. YN CA, churches, etc.).

- Vork closely with principal and staff to learn the school needs

1. Distribute request forms. Clear with principal as to manner of distribution; 1.e., at faculty meetings or in teachers'? boxes.

2. Collect request forms. If the forms are incomplete or if there are any questions in regard to the request, it is wise to take the time to talk personally to the teacher. If verbal requests are recelved, write them on the request forms. 
3. Clear requests with the principal or his representative. reachers and school stafl shall determine the responsibllity for the kinds of tasks to be assigned volunteers and for the supervision of volunteer activity.

4. Add to the request forms any additional information which might prove helpful in finding the right volunteer.

5. If the request cannot be filled locally, the request form obould be forwarded to the section coordinator to be fllled from the section volunteer pool.

6. Keep a flle of all request forms indicating volunteer aselgaed each request.

- Recruitment of volunteers

1. Feleases through the news medis will be made by the school district or with the permisaton of the Ciffice of information.

2. A brief pamphlet describing the program will be publishod by the school district. Included will be an "Indication of interest" card.

3. At the local school level, the recruitment of volunteers is tlexible and is dependent on the individual situation Possible approaches may include a letter from the P TA president to every parent, a house-to-house survey, speeches to local gatherings, etc.

4. Recruitment may be delegated to a committee, the OTA, or some other interested organization. The school coordinator, how ever, maintains the responsibility of recruitment in her achool nelghborhood.

\section{- Interviewing}

1. Interviews may be held by section coordinators, school coordinators, or other deslenated persons. In most situations the school coordinator may assume this responstbllity since volunteers generally feel more comfortable when they are interviewed locally.

2. Interviews will be held at the convenjence of the volunteers.

3. The interview will be conducted to determine the aren of the rolunteer's greatest effectiveness. The volunteer will agree to basic ascumptions of the VIPE program and will recelve all necesary information as to I 3 testing, workshops and placement procedures.

4. The interview should be conducted $28800 \mathrm{n} 28$ possible after a prospective volunteer has indicated interest in VIPE. 
Placement

1. Assignments will be made whenever possible by school coordinators. If a school coordinator is unable to fill a request, the assignment will be made by the section coordinator.

2. The school coordinator is responsible for notifying teacher, principal, and volunteer when a placement is made.

3. The school coordinator shall make arrangements for the prospective volunteer to visit her assigned school and to meet the teacher with whom whe will work.

4. The teacher must outline clearly the assistance she desires from the volunteer.

5. The teacher has the ultimate responsibility for accepting the volunteer. If the arrangem ent is mutually satisfactory to teacher and volunteer, the volunteer is placed.

6. Placement should occur as soon as possible after a request for volunteer services is recelved.

- Follow-up

1. The school coordinator must keep in touch with both teachers and volunteers. She should establish rapport so that she will hear complaints as well as compliments.

2. Immediate evaluation follow-up should be conducted following an individual's first volunteer assignment. The school coordinator will, in most cases, be responsible for irsuring that the teacher and/or principal reports on the effectiviness of the individual.

3. The school coordinator will see that a thank you letter is sent each volunteer on completion of her volunteer duty.

- Fiecord Keeping

1. The school coordinator shall keep a complete flle on all volunteers from her neighborhood. She shall forward information on each volunteer to the section coordinator.

2. The school coordinator shall keep records of volunteer assignments (to whom, nature of assignment, day and time). Information on each volunteer assignment should be forwarded to the section coordinator.

* Forms

1. A personal interview form and a questionnaire on community resources should be completed for each volunteer. These forms should be on flle with the local school coordinator. Wen a volunteer does not wish an assignment at her local 
school or lives outside the program area, all information concerning the volunteer will be kept by the section coordinator.

2. A basic information card for each volunteer shall be forwarded to the section coordinator by the school coordinator. This card shall be placed in the section file.

3. There are two kinds of request form.s. The Community Resource Cnnfirmation form has four coples: white for teacher, yellow for volunteer, plak for school coordinator, and gold for section coordinator. The request form for 2 more general kind of help in the classroom has two coples: yellow for school coordinator and white for section coordinator. 
APPENDIX B

\section{EVALUATIVE INSTRUMENTS}

PAGE

Questionnaire to Determine Volunteer Level of Support

for the School System and for School Volunteerism..... 99

Reply Card for Volunteer Assignment............... 100 
Date

School

Have you served in the schools as a VIPS volumteer? Yes

No

If your enswer to the preceding question is Yes, please indicate the approximate number of hours you have served as a VIPS volunteer this school year.

\begin{tabular}{|c|c|c|c|c|c|}
\hline $\begin{array}{l}\text { INSTRUCTIONS: Below you will find ten statements concerning the Portland } \\
\text { Public Schools. Read each statement. Then place an } X \text { in } \\
\text { the appropriate box on the right to indicate your attitude } \\
\text { toward each of the statements. Onit an } X \text { if you do not } \\
\text { understand the statement. }\end{array}$ & 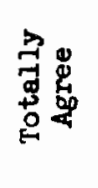 & 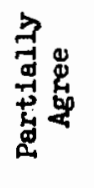 & 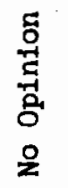 & 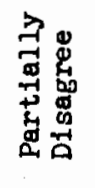 & 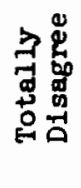 \\
\hline 1. I support the Portland Public Schools and their programs. & & & & & \\
\hline $\begin{array}{l}\text { 2. The Portland School District must gain additional money to properly } \\
\text { meet the needs of the community. }\end{array}$ & & & & & \\
\hline 3. The Portland Public Schools are doing a good job of educating students. & & & & & \\
\hline $\begin{array}{l}\text { 4. Citizens should have a greater role in determining the educational } \\
\text { program at the individual school level. }\end{array}$ & & & & & \\
\hline 5. Clasges are generally too large. & & & & & \\
\hline $\begin{array}{l}\text { 6. The schools should serve es community centers by providing facilities } \\
\text { and programs during the late afternoon, evenings, weekends, and } \\
\text { vacation periods. }\end{array}$ & & & & & \\
\hline 7. Students should recelve more Individual attention. & & & & & \\
\hline $\begin{array}{l}\text { 8. A proportionally greater amount of money per student should be spent on } \\
\text { the education of the culturally and economically deprived. }\end{array}$ & & & & & \\
\hline 9. Volunteers may be used to Increase a teacher's effectiveness. & & & & & \\
\hline $\begin{array}{l}\text { 10. Additional money for the Portland Public Schools should come from local } \\
\text { taxation. }\end{array}$ & & & & & \\
\hline
\end{tabular}


Name

Address Phone

VOLUNTEER ASSICNMENT.

School Teacher Crade

Dates of assignment

Approximate number of hours spent in assignment Nature of assignment 